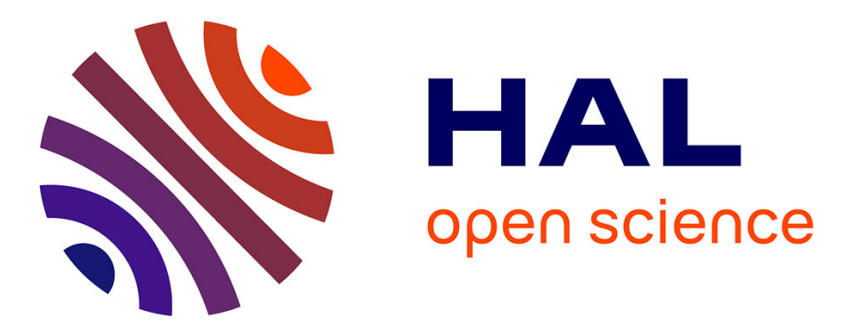

\title{
One million cubic kilometers of fossil ice in Valles Marineris: Relicts of a 3.5 Gy old glacial landsystem along the Martian equator
}

Marine Gourronc, Olivier Bourgeois, Daniel Mège, Stéphane Pochat, Benjamin Bultel, Marion Massé, Laetitia Le Deit, Stéphane Le Mouélic, Denis Mercier

\section{To cite this version:}

Marine Gourronc, Olivier Bourgeois, Daniel Mège, Stéphane Pochat, Benjamin Bultel, et al.. One million cubic kilometers of fossil ice in Valles Marineris: Relicts of a 3.5 Gy old glacial landsystem along the Martian equator. Geomorphology, 2014, 204, pp.235-255. 10.1016/j.geomorph.2013.08.009 . hal-02430111

\section{HAL Id: hal-02430111 \\ https://hal.science/hal-02430111}

Submitted on 7 Jan 2020

HAL is a multi-disciplinary open access archive for the deposit and dissemination of scientific research documents, whether they are published or not. The documents may come from teaching and research institutions in France or abroad, or from public or private research centers.
L'archive ouverte pluridisciplinaire HAL, est destinée au dépôt et à la diffusion de documents scientifiques de niveau recherche, publiés ou non, émanant des établissements d'enseignement et de recherche français ou étrangers, des laboratoires publics ou privés. 


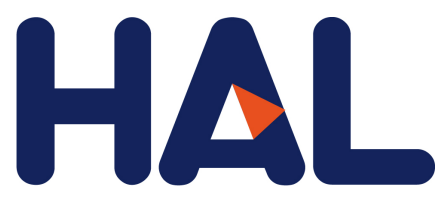

archives-ouvertes

\section{One million cubic kilometers of fossil ice in Valles Marineris: Relicts of a 3.5 Gy old glacial landsystem along the Martian equator}

Stéphane Pochat, Marine Gourronc, Olivier Bourgeois, Daniel Mège, Benjamin Bultel, Marion Massé, Laetitia Le Deit, Stéphane Le Mouélic, Denis Mercier

\section{To cite this version:}

Stéphane Pochat, Marine Gourronc, Olivier Bourgeois, Daniel Mège, Benjamin Bultel, et al.. One million cubic kilometers of fossil ice in Valles Marineris: Relicts of a 3.5 Gy old glacial landsystem along the Martian equator. Geomorphology, Elsevier, 2014, 204, pp.235-255. 10.1016/j.geomorph.2013.08.009 . hal-02430111

\section{HAL Id: hal-02430111 https://hal.archives-ouvertes.fr/hal-02430111}

Submitted on 7 Jan 2020

HAL is a multi-disciplinary open access archive for the deposit and dissemination of scientific research documents, whether they are published or not. The documents may come from teaching and research institutions in France or abroad, or from public or private research centers.
L'archive ouverte pluridisciplinaire HAL, est destinée au dépôt et à la diffusion de documents scientifiques de niveau recherche, publiés ou non, émanant des établissements d'enseignement et de recherche français ou étrangers, des laboratoires publics ou privés. 


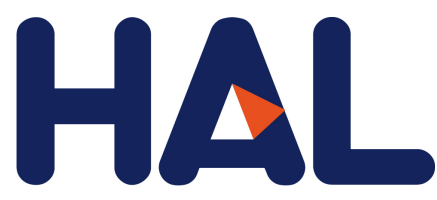

archives-ouvertes

\section{One million cubic kilometers of fossil ice in Valles Marineris: Relicts of a 3.5 Gy old glacial landsystem along the Martian equator}

Marine Gourronc, Olivier Bourgeois, Daniel Mège, Stéphane Pochat, Benjamin Bultel, Marion Massé, Laetitia Le Deit, Stéphane Le Mouélic, Denis Mercier

\section{To cite this version:}

Marine Gourronc, Olivier Bourgeois, Daniel Mège, Stéphane Pochat, Benjamin Bultel, et al.. One million cubic kilometers of fossil ice in Valles Marineris: Relicts of a 3.5 Gy old glacial landsystem along the Martian equator. Geomorphology, Elsevier, 2014, 204, pp.235-255. 10.1016/j.geomorph.2013.08.009 . hal-02430111

\section{HAL Id: hal-02430111 https://hal.archives-ouvertes.fr/hal-02430111}

Submitted on 7 Jan 2020

HAL is a multi-disciplinary open access archive for the deposit and dissemination of scientific research documents, whether they are published or not. The documents may come from teaching and research institutions in France or abroad, or from public or private research centers.
L'archive ouverte pluridisciplinaire HAL, est destinée au dépôt et à la diffusion de documents scientifiques de niveau recherche, publiés ou non, émanant des établissements d'enseignement et de recherche français ou étrangers, des laboratoires publics ou privés. 


\title{
One million cubic kilometers of fossil ice in Valles Marineris: Relicts of a 3.5 Gy old glacial landsystem along the Martian equator
}

\author{
Marine Gourronc ${ }^{\mathrm{a}, \mathrm{b}, *}$, Olivier Bourgeois ${ }^{\mathrm{a}, \mathrm{b}}$, Daniel Mège ${ }^{\mathrm{a}, \mathrm{b}, \mathrm{c}}$, Stéphane Pochat ${ }^{\mathrm{a}, \mathrm{b}}$, Benjamin Bultel ${ }^{\mathrm{d}}$, \\ Marion Massé ${ }^{c}$, Laetitia Le Deit ${ }^{e}$, Stéphane Le Mouélic ${ }^{\mathrm{a}, \mathrm{b}}$, Denis Mercier ${ }^{\mathrm{b}, \mathrm{f}}$ \\ a Laboratoire de Planétologie et Géodynamique de Nantes, CNRS UMR6112, Université de Nantes, 2 rue de la Houssinière, BP92208, 44322 Nantes Cedex 3, France \\ b OSUNA, Nantes, France \\ c Institute of Geological Sciences, Polish Academy of Sciences, Research Centre in Wrockaw, Poland \\ d Laboratoire de géologie de Lyon, Terre, Planète, Environnement, Université Claude Bernard Lyon 1, Lyon, France \\ e Institute of Planetary Research, German Aerospace Center (DLR), Berlin, Germany \\ ${ }^{\mathrm{f}}$ LETG, CNRS UMR 6554, Université de Nantes, Nantes, France
}

\section{A R T I C L E I N F O}

\section{Article history:}

Received 2 April 2013

Received in revised form 6 August 2013

Accepted 15 August 2013

Available online $\mathrm{xxxx}$

\section{Keywords:}

Glaciation

Valles Marineris

Mars

Hesperian

\begin{abstract}
A B S T R A C T
Self-consistent landform assemblages suggest that Valles Marineris, the giant valley system that stretches along the Martian equator, was entirely glaciated during Late Noachian to Early Hesperian times and still contains huge volumes of fossil ice. Some of these glacial landform assemblages are illustrated here, with representative examples selected in three regions: Ius Chasma, Central Candor Chasma and the junction between Coprates Chasma and Capri Chasma. A morphological boundary separating an upper spur-and-gully morphology from a smooth basal escarpment has been spectacularly preserved along valley walls throughout Valles Marineris. The boundary winds around topographic obstacles and displays long-wavelength variations in elevation. It is associated with lateral benches, hanging valleys and truncated spurs. Comparisons with terrestrial analogs indicate that it is most reasonably interpreted as a glacial trimline. Chasma floors are covered by various kinds of terrains, including hummocky terrains, platy terrains, lateral banks, layered benches and a draping mantle. Landforms in these terrains and their spatial relationship with the interpreted trimline suggest that they correspond to various disintegration stages of an ancient glacial fill, currently protected by a superficial cover of ablation till. Altogether, these landforms and terrains compose a full glacial landsystem with wet-based glaciers that were able to flow and slide over their beds. It was most probably fed by ice accumulating at low elevations directly from the atmosphere onto valley floors and walls, with only minor contributions from tributary glaciers flowing down from higher elevations. Similar fossil glacial landsystems dating back from the early Martian history are to be expected in many other low-latitude troughs such as chasmata, chaos, valleys, impact craters and other basins.
\end{abstract}

\section{Introduction}

The current climatic conditions do not allow significant accumulations of surface ice at low latitudes on Mars (Fanale et al., 1986; Baker, 2001). Therefore, present-day Martian glaciers comprise only two polar ice sheets (e.g., Fishbaugh and Head, 2001) and a number of icefilled craters scattered at northern and southern latitudes higher than $70^{\circ}$ (Armstrong et al., 2005; Conway et al., 2012). Theoretical considerations on the stability of water ice and climate numerical simulations however predict that surface ice accumulation areas may have shifted repeatedly between polar, middle, tropical, and equatorial latitudes in the past in response to changes in Martian orbital and atmospheric characteristics (Jakosky and Carr, 1985; Mischna et al., 2003; Levrard

\footnotetext{
* Corresponding author at: Laboratoire de Planétologie et Géodynamique de Nantes, CNRS UMR6112, Université de Nantes, 2 rue de la Houssinière, BP92208, 44322 Nantes Cedex 3, France. Tel.: + 33276645153.

E-mail address: marine.gourronc@univ-nantes.fr (M. Gourronc).
}

et al., 2004; Forget et al., 2006; Madeleine et al., 2009; Wordsworth et al., 2013).

In accordance with these theoretical and numerical predictions, abundant observational evidence of past glaciations has been described at Martian polar to tropical latitudes. These include currently debriscovered glaciers, observed for instance east of Hellas Basin and at Olympus Mons (Squyres, 1978, 1979; Milkovich et al., 2006; Holt et al., 2008), and landforms interpreted as remnants of extensive glacial landsystems: mountain glaciers, valley glaciers, piedmont glaciers, and plateau ice sheets, observed in various regions such as Nilosyrtis Mensae, Arabia Terra, southern Deuteronilus-Protonilus Mensae, Phlegra Montes (Head et al., 2005, 2006a, 2006b; Head and Marchant, 2006; Levy et al., 2007; Dickson et al., 2008, 2010; Head et al., 2010). Glacial landforms in these regions are thought to be related to Amazonian cold-based glaciations (Head et al., 2006a,b; Head and Marchant, 2006; Levy et al., 2007; Dickson et al., 2010). Based on the existence of networks of sinuous ridges resembling terrestrial eskers, wet-based glaciations also have been hypothesized at northern and 
southern latitudes higher than $30^{\circ}$. These glaciations are thought to be Amazonian in age, except for one late Noachian or early Hesperian instance in the Dorsa Argentea formation near the present-day South Polar Cap (Kargel and Strom, 1992; Fastook et al., 2012).

On the other hand, little morphological evidence of past glacial activity has been described so far in equatorial regions, except for some mountain glaciers on Tharsis volcanoes (Head and Marchant, 2003; Shean et al., 2005), for some crater fills in Sinus Sabaeus and in the region of Aram Chaos (Massé, 2010; Shean, 2010), and for a number of individual landforms (U-shaped valleys, hanging valleys, arêtes, lateral moraines, ablation moraines, scours, flow-like valley fills) scattered in Valles Marineris (Rossi et al., 2000; Chapman et al., 2005; Thaisen et al., 2008; Fueten et al., 2011). Mège and Bourgeois (2011) also noticed that the upper parts of chasma walls in numerous regions of Valles Marineris display a ‘spur-and-gully' morphology typical of terrestrial periglacial environments, whereas their lower parts generally comprise smooth basal escarpments resembling glacially trimmed surfaces (Chapman et al., 2005). Mège and Bourgeois (2011) interpreted the contact between these two distinct morphologies as a glacial trimline, i.e., a morphological boundary marking the maximal elevation of an ancient glacial fill (Ballantyne and Harris, 1994). In addition, crestal grabens and uphill-facing fault scarps observed on most basement ridges in Valles Marineris have been interpreted as indicating deep-seated gravitational ridge spreading produced by paraglacial topographic readjustments (Mège and Bourgeois, 2011).

Though these various features have been individually attributed to the former presence of glaciers, no systematic review or regional correlation of glacial landforms in Valles Marineris has been published so far. The present work is an attempt at filling this gap so as to demonstrate that these individual landforms compose collectively a self-consistent glacial assemblage. For that purpose, we describe and compare landforms in three regions located in the western, central, and eastern parts of Valles Marineris, respectively: Ius Chasma, central Candor Chasma, and the junction between Coprates Chasma and Capri Chasma (Fig. 1). To explore the cartographic and altitudinal relationships between these landforms, we use images acquired by the Context Camera (CTX) and the High Resolution Imaging Science Experiment (HiRISE) as well as altimetry single track data obtained from the Mars

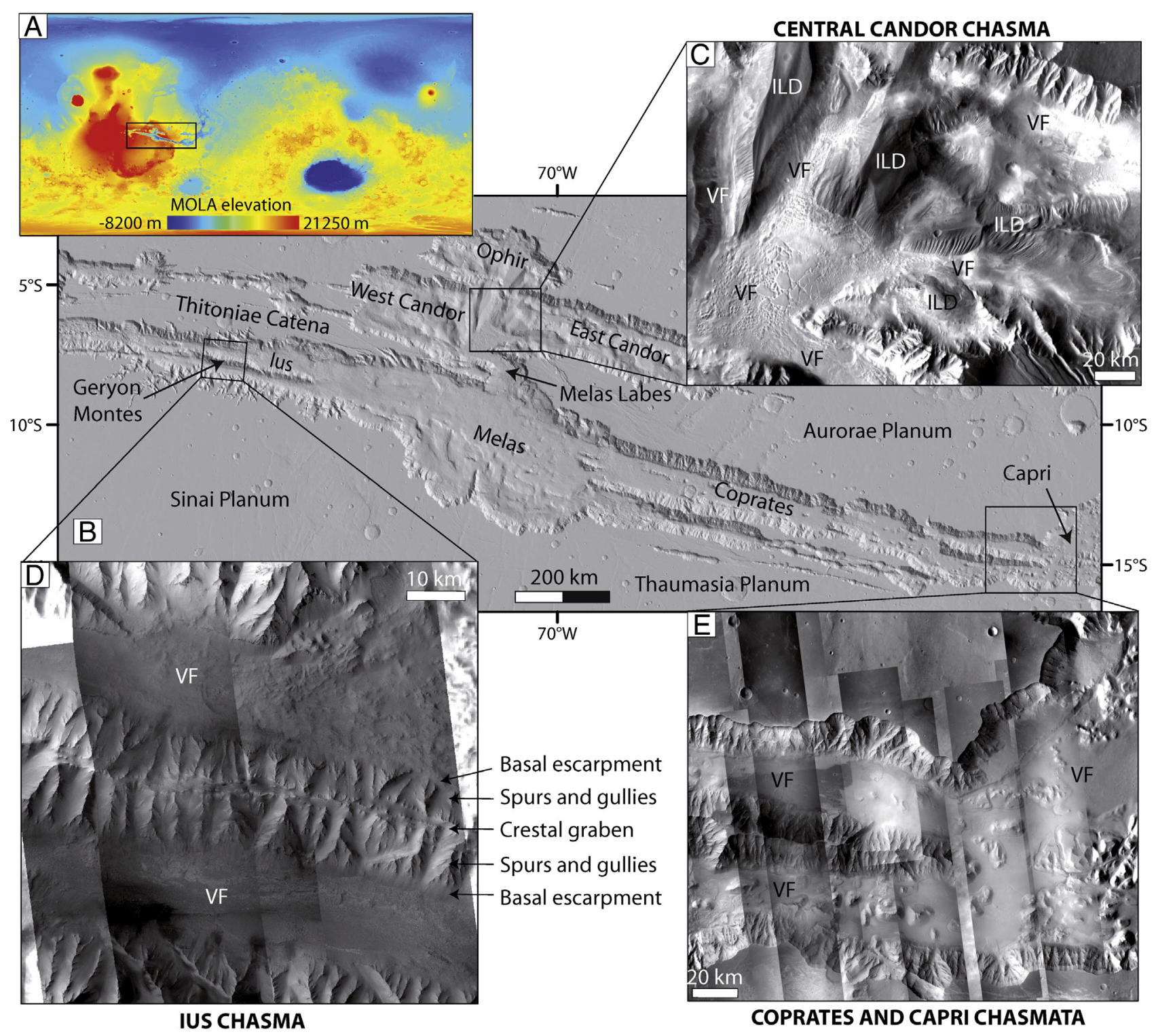

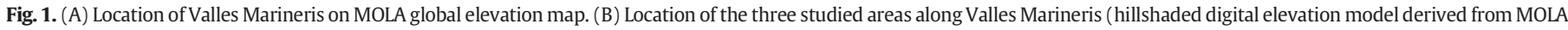

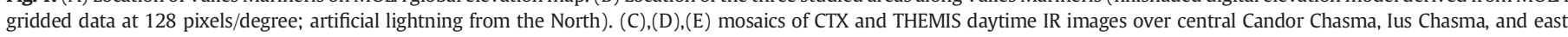
Coprates Chasma, respectively. ILD $=$ interior layered deposits, $\mathrm{VF}=$ valley fill. 
Orbital Laser Altimeter (MOLA) Precision Experiment Data Records (PEDR). We discuss candidate geological processes that could have generated each of these landforms individually, and we compile regional maps and cross sections of various geomorphological features that can be interpreted as having a glacial origin.

We demonstrate that these landforms compose altogether an extensive relict glaciated valley landsystem (Evans, 2005), which supports the idea that massive wet-based ice deposits have formed at the Martian equator during the late Noachian or early Hesperian and have been preserved for their larger part until the present day.

\section{Physiographic setting}

Valles Marineris is a valley system that strikes over $2000 \mathrm{~km}$ along the Martian equator (Fig. 1). Its central part is composed of connected valleys (chasmata) up to $100 \mathrm{~km}$ in width, several hundred kilometers in length, and 2 to $8 \mathrm{~km}$ in depth (Sharp, 1973; Blasius et al., 1977). It may be separated into two subsystems: the southern system comprises Ius Chasma, Melas Chasma, and Coprates Chasma, while the northern one comprises west Candor Chasma, central Candor Chasma, east Candor Chasma, and Ophir Chasma. Both subsystems are connected through Melas Labes, a narrow valley striking NW-SE between Melas Chasma and central Candor Chasma. Valles Marineris is thought to be basically a system of alternating grabens and horsts associated with large-scale collapse depressions that recorded a complex history of tectonic, erosional, and depositional processes (Lucchitta, 1977, 1979, 1981; Nedell et al., 1987; Lucchitta et al., 1992; Peulvast and Masson, 1993a,b; Lucchitta et al., 1994; Mège and Masson, 1996a,b; Schultz, 1998; Lucchitta, 1999; Schultz, 2000; Peulvast et al., 2001; Chojnacki and Hynek, 2008; Fueten et al., 2008; Le Deit et al., 2008; Okubo et al., 2008; Okubo, 2010; Mège and Bourgeois, 2011; Andrews-Hanna, 2012a,b,c). Chasma walls are composed of volcanic basement rocks (McEwen et al., 1999, Flahaut et al., 2012), and their floors are covered by valley fills (VF) that display morphological evidence of soft sediment deformation but are of hitherto unknown origin (Fig. 1) (Metz et al., 2010). Mounds of internal layered deposits (ILD) rise up to $7000 \mathrm{~m}$ above these VF (Nedell et al., 1987; Komatsu et al., 1993; Lucchitta et al., 1994; Komatsu et al., 2004). To explore these terrains, we focus on three representative regions distributed throughout the Valles Marineris valley system: Ius Chasma, central Candor Chasma, and the junction between Coprates Chasma and Capri Chasma (Fig. 1).

\subsection{Ius Chasma}

Ius Chasma is located in the western part of Valles Marineris and is bordered by Tithonia Catena and Tithonium Chasma in the north and Sinai Planum in the south (Figs. 1, 2, and 3). It is made of two parallel valleys striking east-west, separated by Geryon Montes, a basement ridge about $5 \mathrm{~km}$ in height and $70 \mathrm{~km}$ in width, with crestal grabens on its summit and uphill-facing fault scarps along its flanks (Mège and Bourgeois, 2011). The valleys are $500 \mathrm{~km}$ long, up to $8 \mathrm{~km}$ deep with regard to the neighboring plateaus, and $10-30 \mathrm{~km}$ wide. Both valleys decrease in elevation toward Melas Chasma in the east. Their floors are covered by VF with complex landforms (Metz et al., 2010).

\subsection{Central Candor Chasma}

Central Candor Chasma is located north of the central section of Valles Marineris (Figs. 1, 4, and 5). It is connected to Melas Chasma via the Melas Labes valley. It is a system of seven valleys converging into a large central depression $\sim 70 \mathrm{~km}$ in length and $\sim 50 \mathrm{~km}$ in width. The valleys and the central depression are covered by VF with complex landforms (Lucchitta, 1999; Chapman et al., 2005; Metz et al., 2010). The elevation of the central depression varies between -4700 and $-4400 \mathrm{~m}$. Some valleys have names, while others have not; here, we refer to these valleys with numbers (Fig. 4).

Valley \#1 (Melas Labes), $65 \mathrm{~km}$ long and $25 \mathrm{~km}$ wide, stretches NW-SE from the southern part of the central depression toward Melas Chasma (Fig. 4). Valley \#2, $70 \mathrm{~km}$ long and $25 \mathrm{~km}$ wide, and valley \#3, $120 \mathrm{~km}$ long and $\sim 18 \mathrm{~km}$ wide, strike east-west from the western part of the depression toward west Candor Chasma. These three valleys are separated from each other by basement ridges with crestal grabens on their summits and uphill-facing fault scarps along their flanks (Mège and Bourgeois, 2011).

Other tributary valleys of the central Candor Chasma depression include valley \#4, $\sim 6 \mathrm{~km}$ wide and stretching $\mathrm{N}-\mathrm{S}$ over $\sim 80 \mathrm{~km}$ toward

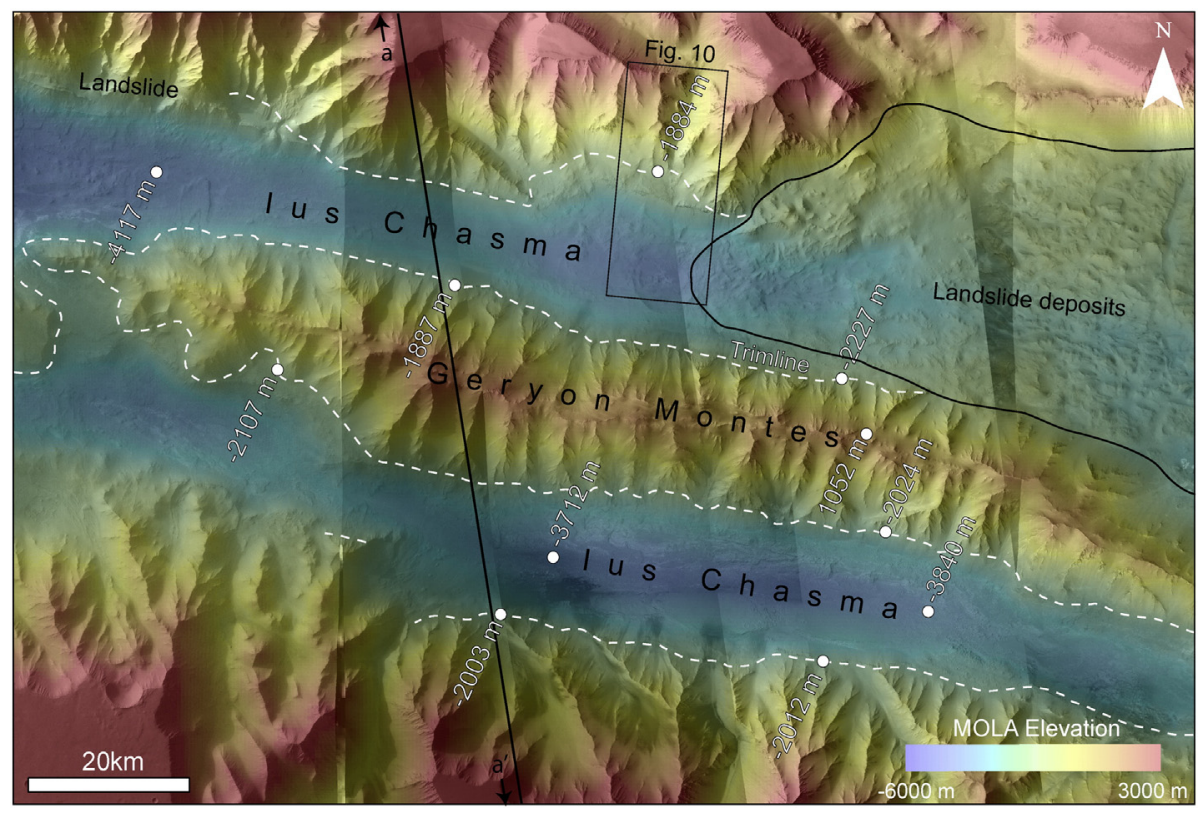

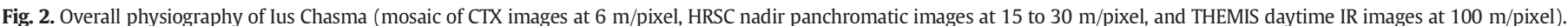

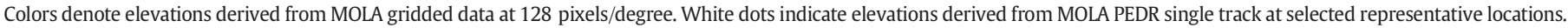

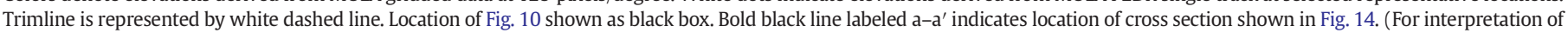
the references to color in this figure legend, the reader is referred to the web version of this article.) 


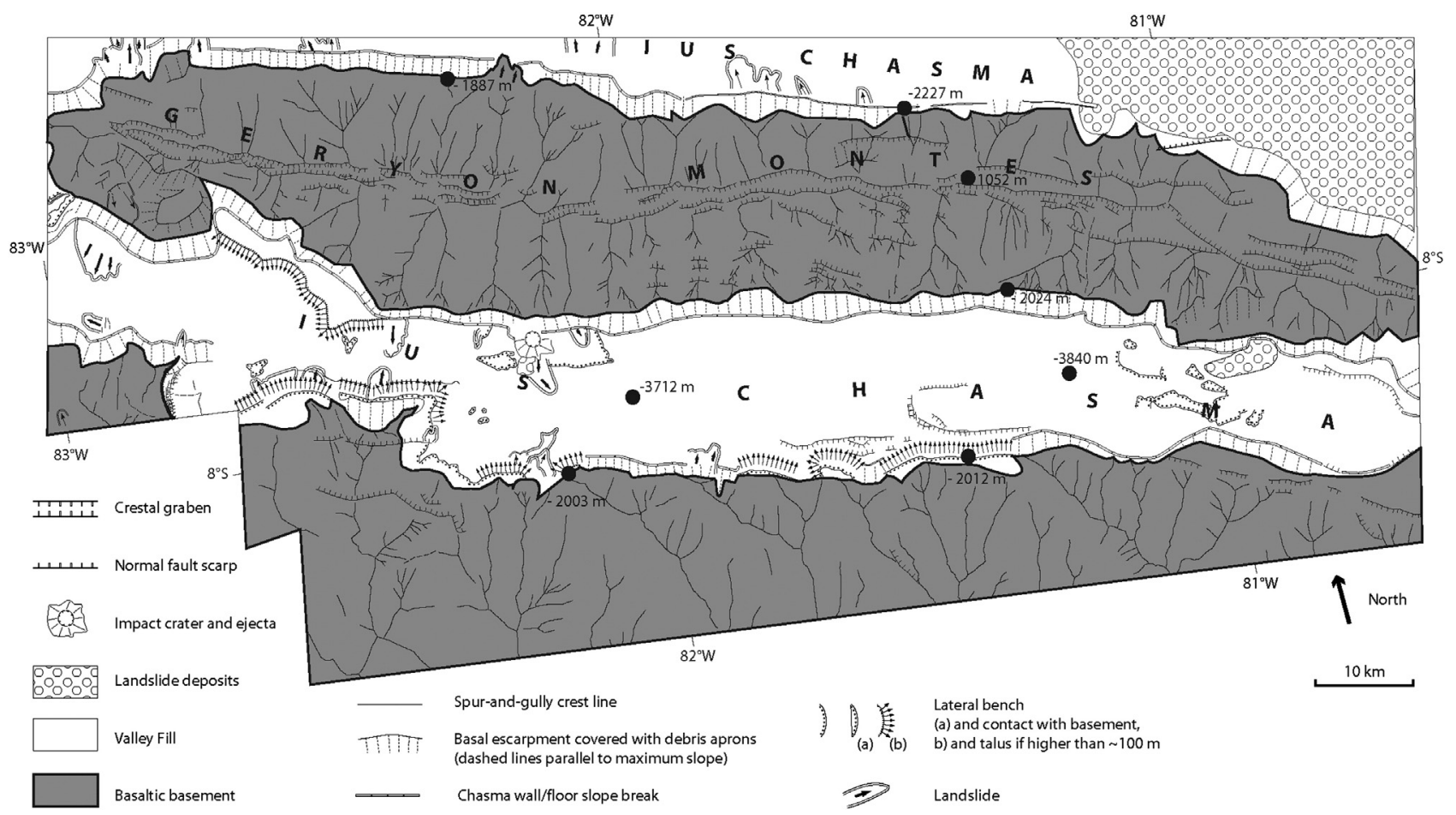

Fig. 3. Geomorphological map of part of Ius Chasma. Black dots indicate elevations derived from MOLA PEDR single tracks at selected representative locations. Modified after Mège and Bourgeois (2011).

Ophir Chasma, between the Baetis Mensa and Candor Mensa ILD mounds. Valley \#5 is $\sim 15-20 \mathrm{~km}$ wide and stretches $\mathrm{N}-\mathrm{S}$ over $\sim 60 \mathrm{~km}$ toward Ophir Chasma, between Baetis Mensa and an unnamed ILD mound (ILD1 in Figs. 4 and 5). Valley \#6 is $\sim 15 \mathrm{~km}$ wide and stretches E-W over $\sim 120 \mathrm{~km}$ toward east Candor Chasma, between unnamed ILD mounds (ILD1, ILD2, and ILD3 in Figs. 4 and 5). The tops of Baetis Mensa, ILD1, and ILD2 mounds are up to $5 \mathrm{~km}$ higher in elevation than the floor of the central depression, while the top of Candor
Mensa is $7 \mathrm{~km}$ higher. Valley \#7, $10 \mathrm{~km}$ wide and $\sim 65 \mathrm{~km}$ long, strikes east-west between two basement ridges with crestal grabens.

\subsection{Junction between Coprates Chasma and Capri Chasma}

Coprates Chasma is located in the eastern part of Valles Marineris. It is bordered by Aurorae Planum in the north and Thaumasia Planum in the south (Figs. 1 and 6). Its easternmost section is a system of two

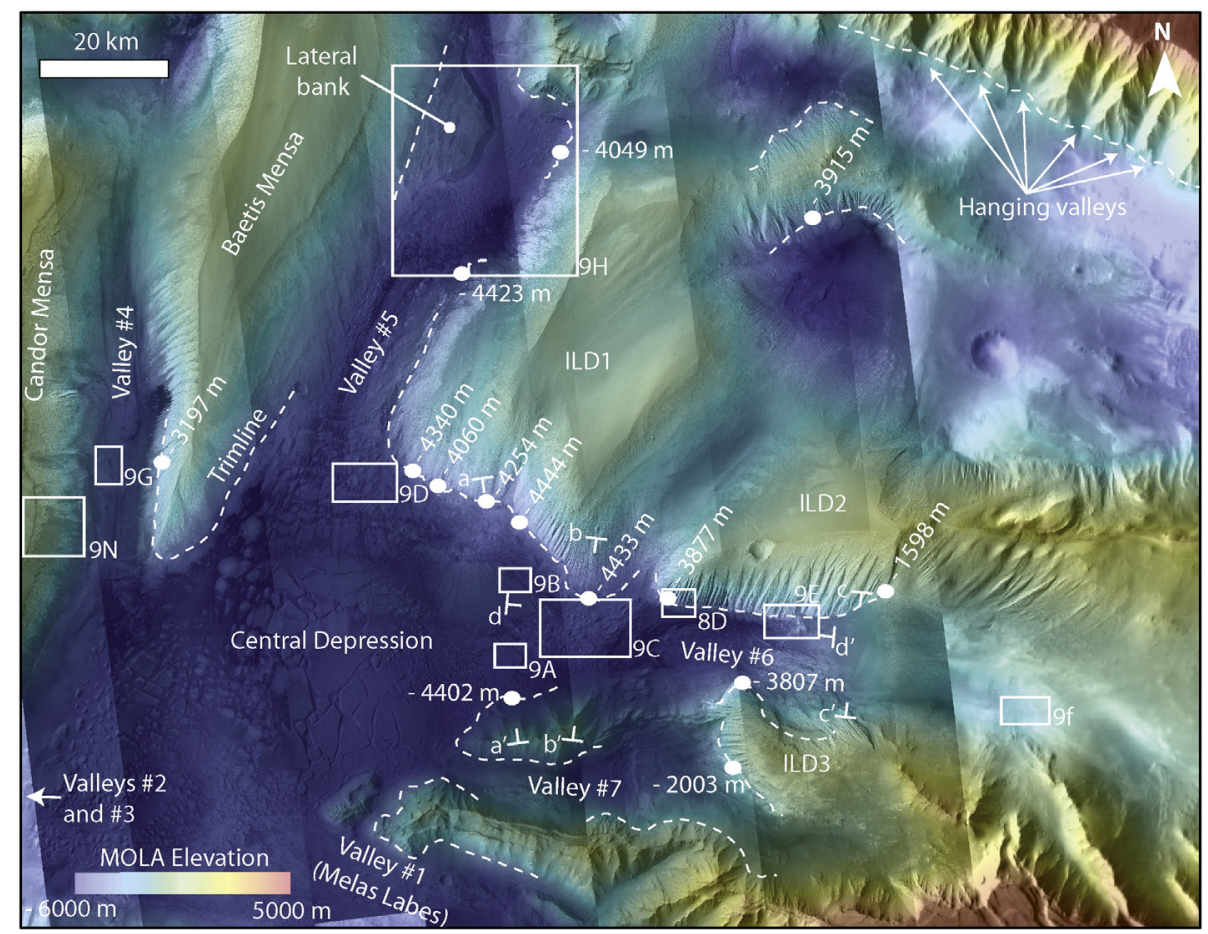

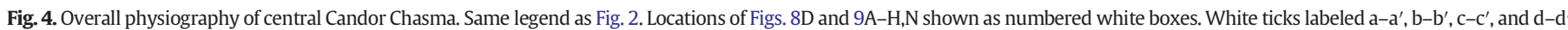
indicate locations of cross sections shown in Fig. 11. (For interpretation of the references to color in this figure legend, the reader is referred to the web version of this article.) 


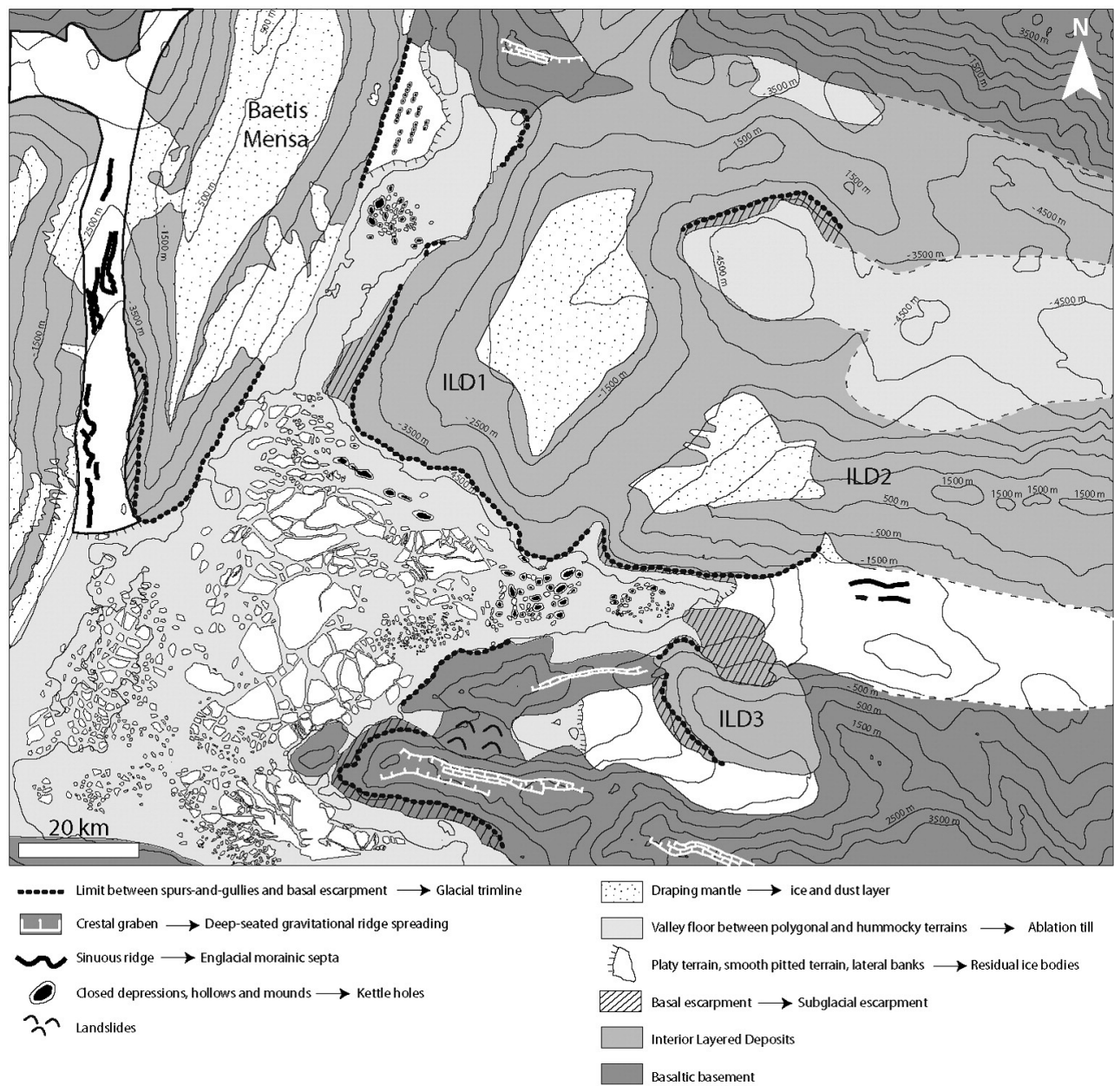

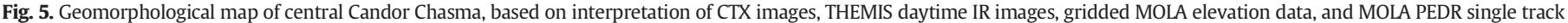
elevation data. Numbered elevation contours (thin black lines) derived from gridded MOLA elevation data.

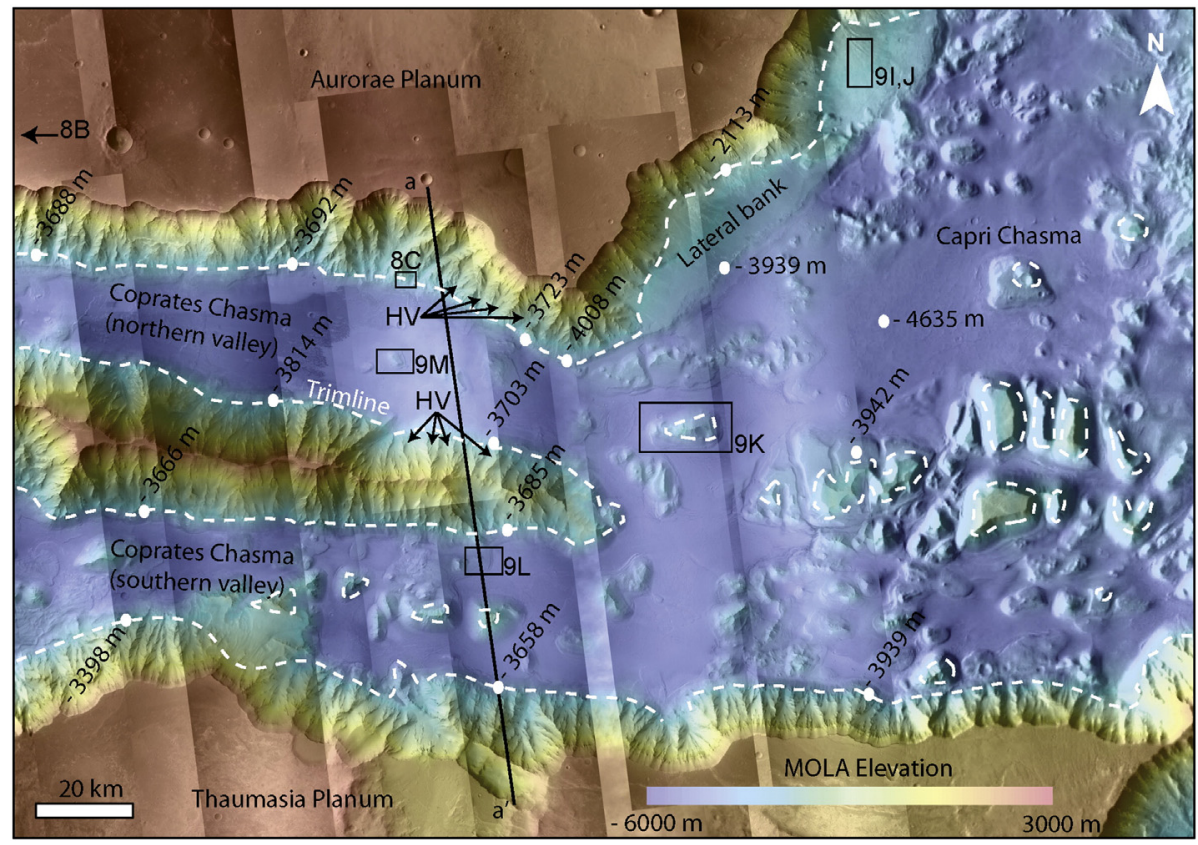

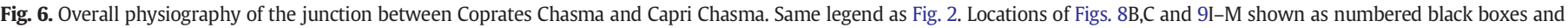

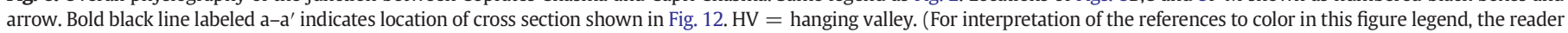
is referred to the web version of this article.) 
valleys striking east-west, separated by a basement ridge about $200 \mathrm{~km}$ in length and 20 to $30 \mathrm{~km}$ in width displaying uphill-facing fault scarps along some of its flanks (Mège and Bourgeois, 2011). The valleys are $\sim 7 \mathrm{~km}$ deep relative to the neighboring plateaus, and they are 15 to $40 \mathrm{~km}$ wide. Both valleys decrease in elevation toward Capri Chasma. They are covered by VF with complex landforms. A number of isolated basement massifs, readily recognized with their rough spur-and-gully morphology (Lucchitta, 1977; Lucchitta et al., 1992; Peulvast and Masson, 1993a,b; Lucchitta et al., 1994; Peulvast et al., 2001; Harrison and Chapman, 2008), rise up to $2000 \mathrm{~m}$ above these VF.

\section{Glacial landforms along valley walls}

\subsection{Spurs, gullies, smooth basal escarpment, and trimline}

Valley walls in most parts of Valles Marineris, be they made of ILDs or of basement rocks, display a spur-and-gully morphology in their upper parts (Figs. 1-7) (Lucchitta, 1977; Lucchitta et al., 1992; Peulvast and Masson, 1993a,b; Lucchitta et al., 1994; Peulvast et al., 2001). By contrast, in many regions, their lower parts comprise smooth basal escarpments partly covered by debris fans and debris aprons (Figs. 1-7) (Chapman et al., 2005; Harrison and Chapman, 2008; Mège and Bourgeois, 2011). The boundary between the morphologically different upper and lower parts of valley walls is well exemplified in Ius Chasma, where it runs along valley walls at an approximate elevation of -1900 to $-2000 \mathrm{~m}$, i.e., 1000 to $2000 \mathrm{~m}$ above valley floors (Fig. 8A).

In central Candor Chasma, this boundary has been particularly well preserved along the northern and southern walls of valley \#6 and along the eastern and western walls of valley \#5 (Figs. 4, 5, and 8D). It winds around topographic obstacles and displays long-wavelength variations in elevation: along valley \#6, its elevation decreases westward from -1600 to $-3900 \mathrm{~m}$; and along valley \#5, its elevation decreases southward from -4050 to $-4400 \mathrm{~m}$. In the central depression, its elevation varies gently from -4000 to $-4300 \mathrm{~m}$.

At the junction between Coprates Chasma and Capri Chasma, the morphological boundary runs along valley walls and winds around basement massifs that project above valley floors (Figs. 6 and 7). Its approximate elevation is $-3300 \mathrm{~m}$ in the western part of the studied region (Fig. 8B), $-3700 \mathrm{~m}$ in its central part (Fig. 8C) and decreases down to $-4000 \mathrm{~m}$ at the outlet of Coprates Chasma into Capri Chasma (Fig. 6). Below the morphological boundary, elevation contours wave significantly on the basal escarpment surface (Fig. 8B).

The basal escarpment was first interpreted as a normal fault plane (Peulvast and Masson, 1993a,b; Mège and Masson, 1996a,b; Schultz, 1998, 2000; Peulvast et al., 2001). This interpretation is at odds with (i) the absence of segmentation, a feature commonly observed in tectonic extension zones on Earth and in deformation experiments, but never observed here; (i i the systematic absence of scarp tapering toward the necessary fault tips (where displacement becomes null); and (i i i) the fact that it winds around topographic obstacles (Mège and Bourgeois, 2011). Alternatively, the top of the basal escarpment has been interpreted as marking the former surface of an ancient water body (Harrison and Chapman, 2008). This interpretation, however, implies that the top of the scarp reflects an equipotential surface inconsistent with its observed variations in elevation. On the other hand, its continuity, its waving shape, and its variations in elevation all are consistent with its interpretation as a glacial trimline (Chapman et al., 2005; Mège and Bourgeois, 2011), marking the maximum level to which glacier ice has sheared off valley walls (Ballantyne and Harris, 1994).

\subsection{Hanging valleys and truncated spurs}

Throughout Valles Marineris, dozens of tributary valleys hang over the basal escarpment described in Section 3.1 (e.g., Figs. 4, 6, and 8B)

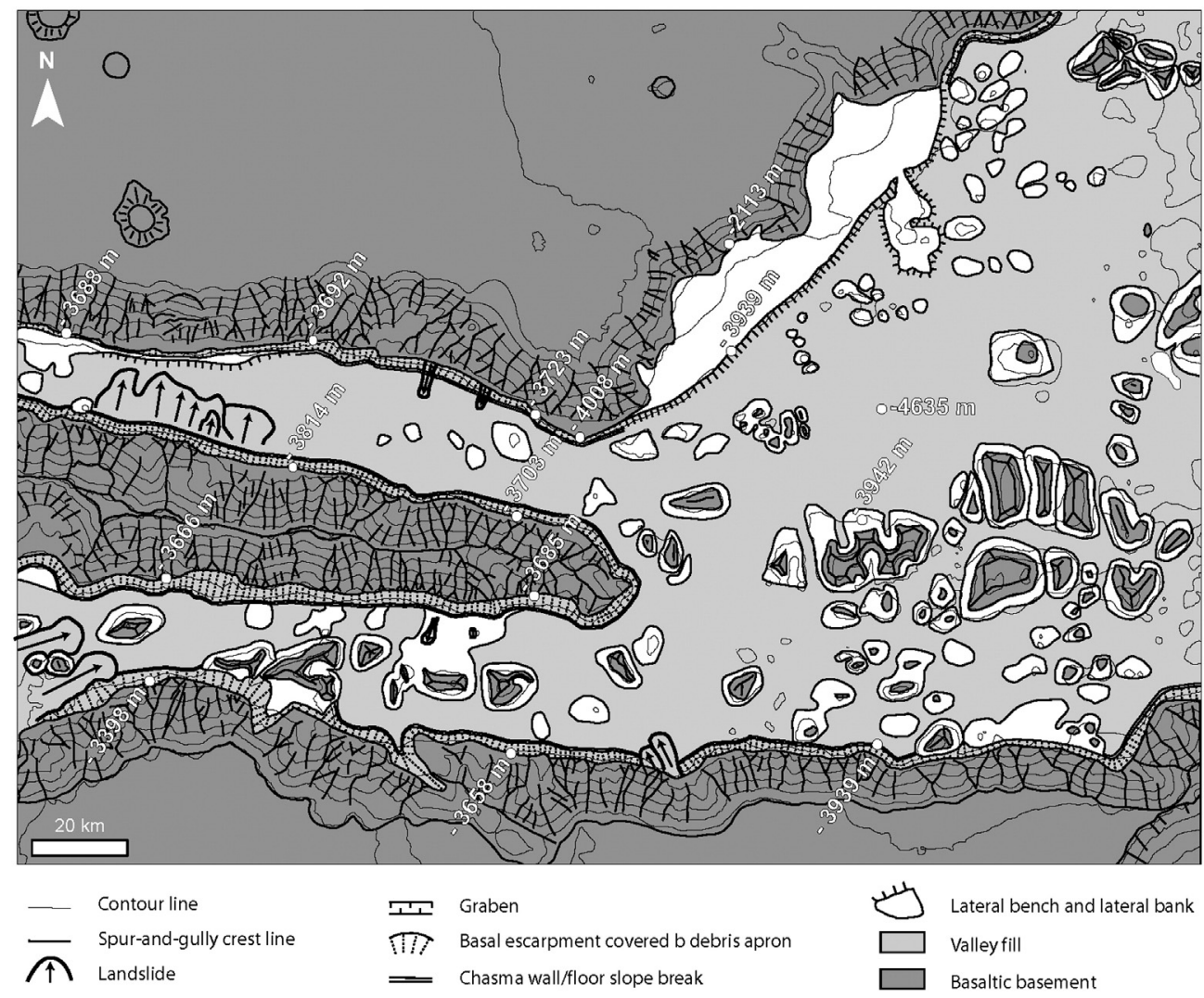

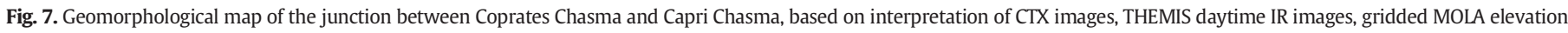

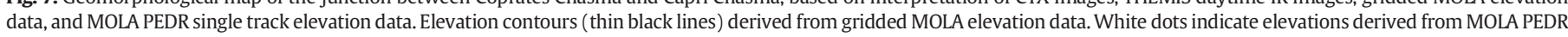
single tracks at selected representative locations. 
(Peulvast and Masson, 1993a,b; Mège and Masson, 1996a,b; Peulvast et al., 2001; Thaisen et al., 2008; Fueten et al., 2011). Tributary valley floors along the walls of Ius Chasma and eastern Coprates Chasma commonly stand $1000 \mathrm{~m}$ to more than $2000 \mathrm{~m}$ above the chasma floor, at the same elevation as the trimline or just above the smooth basal escarpment (Fig. 8A,B). These tributary valleys are separated from one another by basement spurs that end in the form of triangular facets hanging over the smooth basal escarpment (Fig. 8A,B).

On the one hand, the occurrence of alternating valleys and truncated spurs hanging over a smooth basal escarpment may result from tectonic uplift of a normal fault footwall relative to its hanging wall (Hamblin, 1976; Peulvast et al., 2001; Petit et al., 2009). However, we demonstrated in Section 3.1 that a tectonic origin for the basal escarpment is unlikely. On the other hand, this peculiar landform assemblage comprising hanging valleys, truncated spurs, and a continuous waving basal escarpment is frequent along walls of formerly glaciated terrestrial valleys (Benn and Evans, 1998; Evans, 2005). Therefore, we favor the interpretation that the alternation of hanging valleys and truncated spurs along Valles Marineris walls bears witness of the former existence of a glacial system, with minor tributary valley glaciers descending along chasma walls toward major glaciers covering chasma floors.

\subsection{Lateral benches}

At some places in Valles Marineris, the boundary between the spurand-gully morphology and the smooth basal escarpment is underlined by lateral benches. A spectacular occurrence in Ius Chasma is shown in Figs. $8 \mathrm{~A}$ and 10 . These lateral benches have flat tops, and their borders are steep cliffs with debris aprons covering the smooth basal escarpment. In formerly glaciated terrestrial valleys, this kind of bench can result from postglacial preservation of lateral moraines and kame terraces, formed by accumulation along glacier margins of glacifluvial sediments and slope debris derived from valley walls (Evans, 2005). The preserved lateral benches in Valles Marineris follow the interpreted trimline (Fig. 8A), suggesting that they may be either lateral moraines or kame terraces of glacial origin.

\section{Glacial relicts on valley floors}

Chasma floors in Valles Marineris are covered by VF. These encompass widespread, low-elevated, and slightly undulating areas located between chasma walls, basement massifs, and ILD mounds (Fig. 1). Little attention has been paid thus far to the origin and composition of these VF, perhaps because they display a large variety of complex and unfamiliar landforms and because they are sometimes difficult to distinguish from ILD (Lucchitta, 1999; Chapman et al., 2005; Harrison and Chapman, 2008; Flahaut et al., 2010; Metz et al., 2010; Mège and Bourgeois, 2011). Their origin and composition therefore remain enigmatic.

\subsection{Platy terrain}

Platy terrain comprises polygonal plates of various shapes, separated from one another by interconnected rectilinear fractures. In the Candor Chasma's central depression for instance, these plates range from a few meters to a few kilometers in width, with larger plates preferentially located in the central part of the depression (Figs. 4 and 5). Platy terrain was previously interpreted as water-related sedimentary deposits (Lucchitta, 1999). Here, we suggest a glacial interpretation based on the surface morphology of the plates, on the spatial organization of the rectilinear fractures and on the altitudinal relationships between the plates and the trimline.

On their tops, some plates exhibit shallow circular hollows a few hundred meters in diameter. The hollows are organized in lines and, in places, elongate or lobate hollows appear to have grown by coalescence of smaller circular hollows and to have further evolved into fractures (Fig. 9A,B). We infer that a genetic relationship exists between the development and coalescence of these hollows and the development of some fractures between the plates.

A candidate mechanism for the formation and coalescence of these hollows is surface collapse into subsurface cavities associated with a hydrological network, in a way similar to the mechanism of doline formation in terrestrial karstic terrains (Ford and Williams, 2007). An alternative mechanism is roof collapse of lava tubes (Greeley and Hyde, 1972; Greeley and Spudis, 1981; Calvari and Pinkerton, 1998; Wyrick et al, 2004). However, no morphological or structural evidence (faults, fractures, or boulder accumulations) for such a mechanism is visible on the hollow floors. Collapse structures generally have a conical shape (Greeley and Hyde, 1972; Calvari and Pinkerton, 1998; Wyrick et al., 2004; Ford and Williams, 2007), whereas hollows on platy terrains have vertical walls and flat floors. In addition, the spatial organization of hollows and fractures defines networks of interconnected rectilinear lines, which differs from the sinuous planview geometry of underground hydrological networks and lava tubes (Wyrick et al., 2004). Therefore, such collapse formation processes are unlikely.

On the other hand, growth and coalescence of flat-floored hollows along preferential alignments, as described here, is a landform classically produced by ice disintegration at the surface of terrestrial debris-covered glaciers or at glacier margins (Etzelmüller, 2000; Reynolds, 2000; Rohl, 2008). Comparable hollows are thought to have formed by disintegration of ground ice in other regions of Mars (Costard and Kargel, 1995; Malin and Edgett, 2001; Morgenstern et al., 2007; Kadish et al., 2008; Lefort et al., 2009; Le Deit et al., 2010; Mangold, 2011a,b; Séjourné et al., 2011; Soare et al., 2012).

On the basis of these morphological similarities, we suggest that hollows at the surface of platy terrains have formed by partial disintegration of ice bodies. The alignment of hollows and their apparent development by coalescence along linear fractures may be attributed to the fact that they have preferentially formed along preexisting discontinuities in the ice body, such as crevasses or shear zones. Consistent with this interpretation is the fact that the spatial organization of linear fractures at the outlets of valleys \#5 and \#6 and in the southwestern part of the central depression mimics that of longitudinal and transverse crevasses in terrestrial outlet glaciers (Figs. 4 and 5). The surface morphology of platy terrains hence suggests that they are debris-covered ice bodies, analogous to residual ice bodies protected by ablation tills that can remain locally for decades to millions of years after terrestrial glaciers have disintegrated (Ostrem, 1959; Mattson et al., 1993; Kowalewski et al., 2006, 2011).

In central Candor Chasma, the interpretation that the platy terrains are relicts of glaciers that once filled the whole central depression and its tributary valleys is further supported by comparing the elevation of the plates with that of the trimline. Along the northeastern wall of the depression, the trimline is located on the flank of ILD1 mound, at an elevation of $\sim-4250 \mathrm{~m}$ (Figs. 4, 5, and 11A). Along the southeastern wall of the depression, it is located on the basement wallrock at an elevation of $\sim-4400 \mathrm{~m}$. On the depression floor, the elevation of the largest polygonal plates is very close (from -4250 to $-4370 \mathrm{~m}$ ) to that of the trimline, and polygonal plates never exceed the trimline in elevation (Fig. 11A). This is consistent with the interpretation that polygonal plates are fragmented relicts of an ancient glacial body that once covered the whole depression up to the trimline: larger plates currently have an elevation close to that of the trimline because they have been little degraded, whereas smaller plates have lower elevations because they have been more degraded.

\subsection{Hummocky terrain}

Hummocky terrain covers the floor of Valles Marineris in many places, for instance in Ius Chasma (Fig. 10) and in Coprates Chasma (Fig. 8B,C). Its morphology is particularly well exemplified at the junction between valley \#6 and the Candor Chasma central depression 

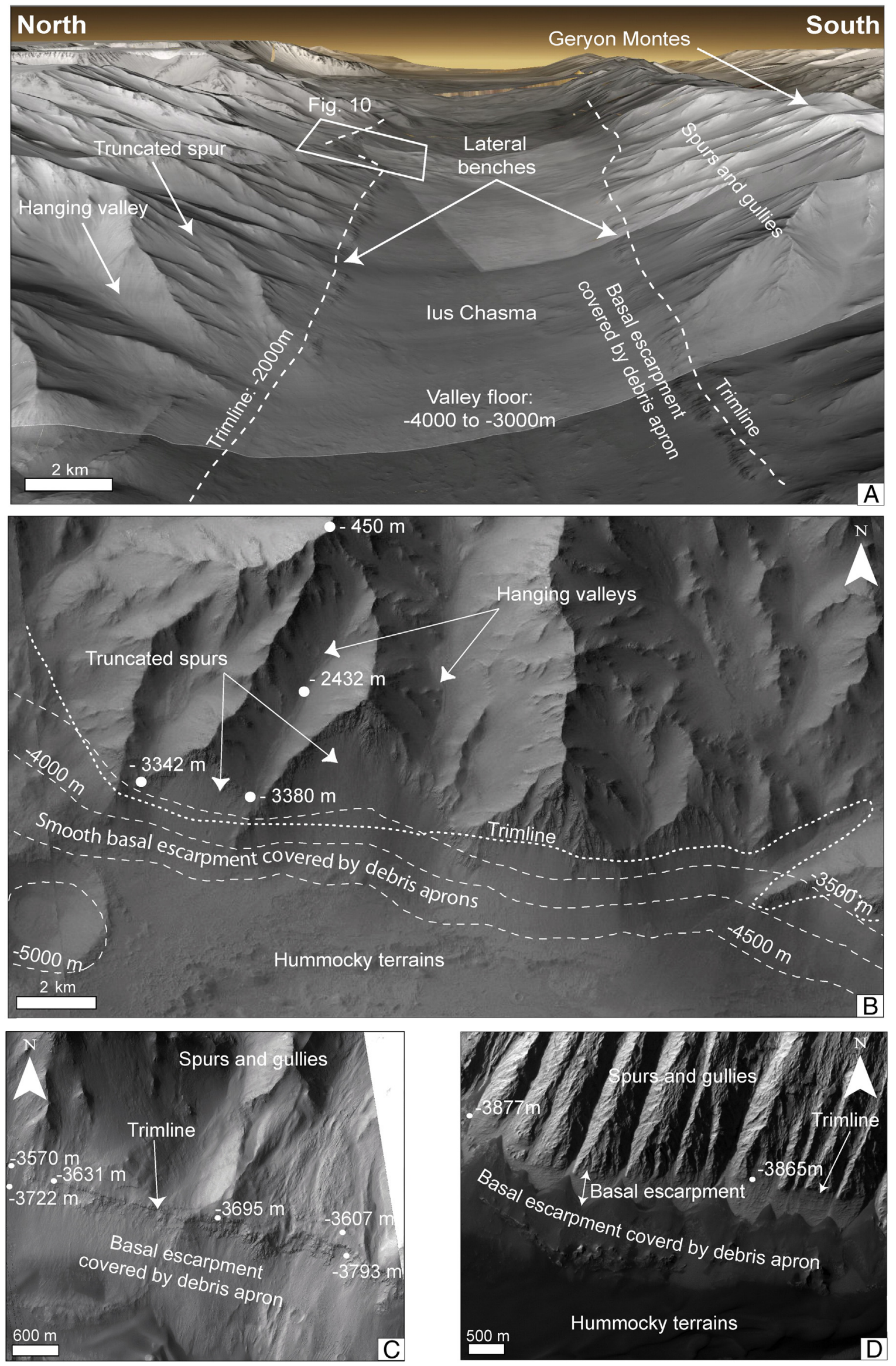
(Figs. 5 and 9C,D,E). In this area, the hummocky terrain includes various irregularly juxtaposed landforms: mounds, mounds with cratered summits, doughnut-shaped features comprising a rim surrounding a shallow central hollow, and closed depressions (Fig. 9C). The largest landforms are doughnut-shaped features, $2 \mathrm{~km}$ in diameter, preferentially located along the axis of valley \#6. By contrast, the smallest ones are mounds, $1 \mathrm{~km}$ in diameter, located along the borders of the valley. Hummocky terrains are systematically lower in elevation than the trimline (Figs. 4, 8B,D, 9E, and 11B). They are also about $300 \mathrm{~m}$ lower in elevation than plate tops of the platy terrain, and there is a progressive morphological transition between both kinds of terrains (Fig. 9D). This transition and the associated difference in elevation suggest that the hummocky terrain corresponds to an advanced disintegration stage of the platy terrain.

Consistent with this interpretation is the fact that the doughnutshaped features and the closed depressions are similar in shape and in size to kettle holes covering formerly glaciated regions of the Earth, such as Alberta, Saskatchewan, and the northern United States (Mollard, 2000). On Earth, hummocky terrain with kettle holes is a classical component of ablation moraines in retreating glacier landsystems and is thought to form by disintegration of residual ice cores during deglaciation (Mollard, 2000; Burr et al., 2009). On the basis of this morphological similarity, Chapman et al. (2005) and Mège and Bourgeois (2011) interpreted the doughnut-shaped features and closed depressions in central Candor Chasma as kettle holes resulting from the disintegration of an ice body. Alternatively, Lucchitta (1999) attributed the formation of these kettle holes to melting of ice blocks rafted into a proglacial outwash plain by catastrophic floods similar to terrestrial jökulhlaups.

On the basis of their spatial and altitudinal relationships with the trimline and with platy terrains, we follow Chapman et al. (2005) and Mège and Bourgeois (2011) and favor the interpretation that the closed depressions have formed by disintegration of an ice body rather than of flood-rafted ice blocks. Therefore, we interpret the hummocky terrain as ablation moraines left after advanced disintegration of a regional ice body, which once filled the valley up to the trimline (Fig. 11B). The distribution and variety of landforms in hummocky terrain in Valles Marineris are consistent with control by the initial structure of the ice body, the size of residual ice cores and the initial amount of supraglacial and englacial rock material, of the final shape of ice disintegration landforms in vanishing glacial landsystems (Maizels, 1992). As ice ablation proceeds, englacial and supraglacial rock debris progressively cover the ice with a layer of ablation till, resulting in the formation of icecored and debris-covered mounds. This superficial debris layer is able to protect the mounds from further disintegration if it gets sufficiently thick (Ostrem, 1959; Mattson et al., 1993; Kowalewski et al., 2006, 2011). This might be the case for some mounds observed along the flanks of valley \#6, some of which have flat tops with elevations similar to that of the trimline (Fig. 11B). By contrast, if the superficial debris layer is thin, continued disintegration of ice cores can result in mound collapse and mass wasting, thus producing kettle holes analogous to the closed depressions and doughnut-shaped features observed along the valley axis (Kjaer and Kruger, 2001).

\subsection{Smooth pitted terrain}

In central Candor Chasma, the smooth basal escarpment of valley walls interpreted as a glacially trimmed surface is visible in the downstream sections of valleys \#4, 5, 6, and 7 (Figs. 4, 5, 8D, and 9E). In the upstream sections of these valleys on the other hand, this smooth basal escarpment is not exposed: it disappears at locations where the surface of the materials that cover valley floors abruptly increases in elevation and nearly meets the trimline (Figs. 4, 5, and 9E).

This is particularly well exemplified in valley \#6. On the one hand, the downstream section of this valley, where the basal escarpment is exposed, is covered by hummocky terrain lying $700 \mathrm{~m}$ below the trimline; on the other hand, its upstream section, where the basal escarpment is not visible, is filled nearly up to the base of the spurand-gully morphology by smooth and flat terrains located a few meters below the trimline (Figs. 4, 5, 9E, and 11C).

These upstream terrains are partially covered with dark sediments and their surface is dotted with numerous circular to elliptic rimless pits a few meters to a few hundred meters in diameter (Fig. 9F). In other places on Mars, pitted textures on smooth surfaces have been attributed to ice ablation processes (Kreslavsky and Head, 2002; Head et al., 2003; Morgenstern et al., 2007; Kadish et al., 2008; Lefort et al., 2009; Mangold, 2011a,b). The surface of this smooth pitted terrain also displays flat circular platters slightly darker than their surroundings (Fig. 9F). These features resemble degraded impact craters that are currently exposed at the surface of the Martian North Polar Cap. Craters produced by impacts on the ice layers of the North Polar Cap progressively disappear by ice ablation on their rims and by ice deposition in their central depressions; this process ultimately leads to the formation of platters similar in size and shape to those described here in Candor Chasma (Banks et al., 2010).

On the basis of these morphological similarities, we interpret the smooth pitted terrains in the upstream section of valley \#6 as a debris-covered ice body resting on the valley floor and masking the smooth basal escarpment along valley flanks (Fig. 11C). The fact that they are a few meters lower in elevation than the trimline and that their surface is dotted with pits resembling ice ablation landforms and with platters resembling degraded impact craters in icy materials is consistent with the idea that these terrains are the surface of a relict glacier that once filled the valley up to the trimline and was latter slightly lowered by ice disintegration.

The floor of valley \#7 displays a similar configuration (Figs. 4 and 5): its downstream section is filled by hummocky terrain located at an elevation of $-4500 \mathrm{~m}$ and partly covered by landslide deposits while its upstream section is filled by smooth pitted terrains ranging from -4000 to $-3800 \mathrm{~m}$ in elevation. The boundary between these two different terrains is a $500 \mathrm{~m}$ high scarp that was previously interpreted as a glacier front (Chapman et al., 2005). The presence of hummocky terrain down this scarp is consistent with the idea that it is the present-day erosional front of a relict glacier that once covered both the upstream and downstream sections of the valley.

The boundary between hummocky terrain and smooth pitted terrain also forms an escarpment $200 \mathrm{~m}$ high at the outlet of valley \#4 into the central depression (Figs. 4 and 5). Upstream from this scarp, valley \#4 is filled by smooth pitted terrains displaying dark sinuous ridges, up to $150 \mathrm{~m}$ wide and $8 \mathrm{~km}$ in length, at their surface (Fig. 9G). These ridges are preferentially located along valley flanks, are parallel to the overall direction of the valley, and their contorted shape suggests that they have been viscously deformed (Fig. 5). The overall shape and location of these ridges mimic that of longitudinal englacial morainic septa exposed by surface ice ablation in terrestrial glaciers (Rogerson et al., 1986; Vere and Benn, 1989). The existence of these ridges in valley \#4 is thus consistent with the interpretation that smooth pitted terrains filling the upstream sections of central Candor Chasma valleys are slightly degraded relict glaciers mantled with a debris layer.

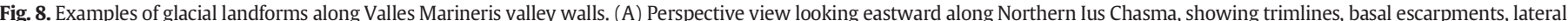

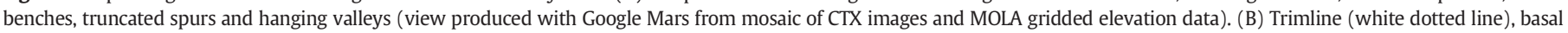

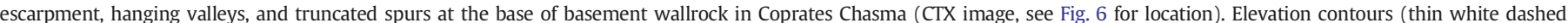

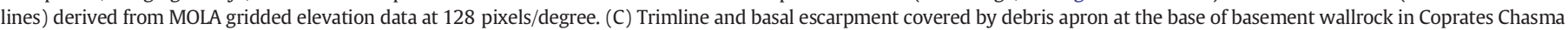

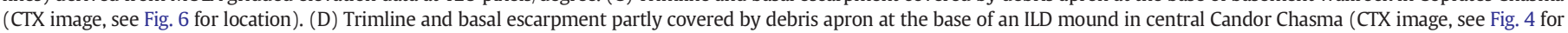
location). On (A)-(D), white dots indicate elevations derived from MOLA PEDR single tracks at selected representative locations. 
M. Gourronc et al. / Geomorphology xxx (2013) xxx-xxx
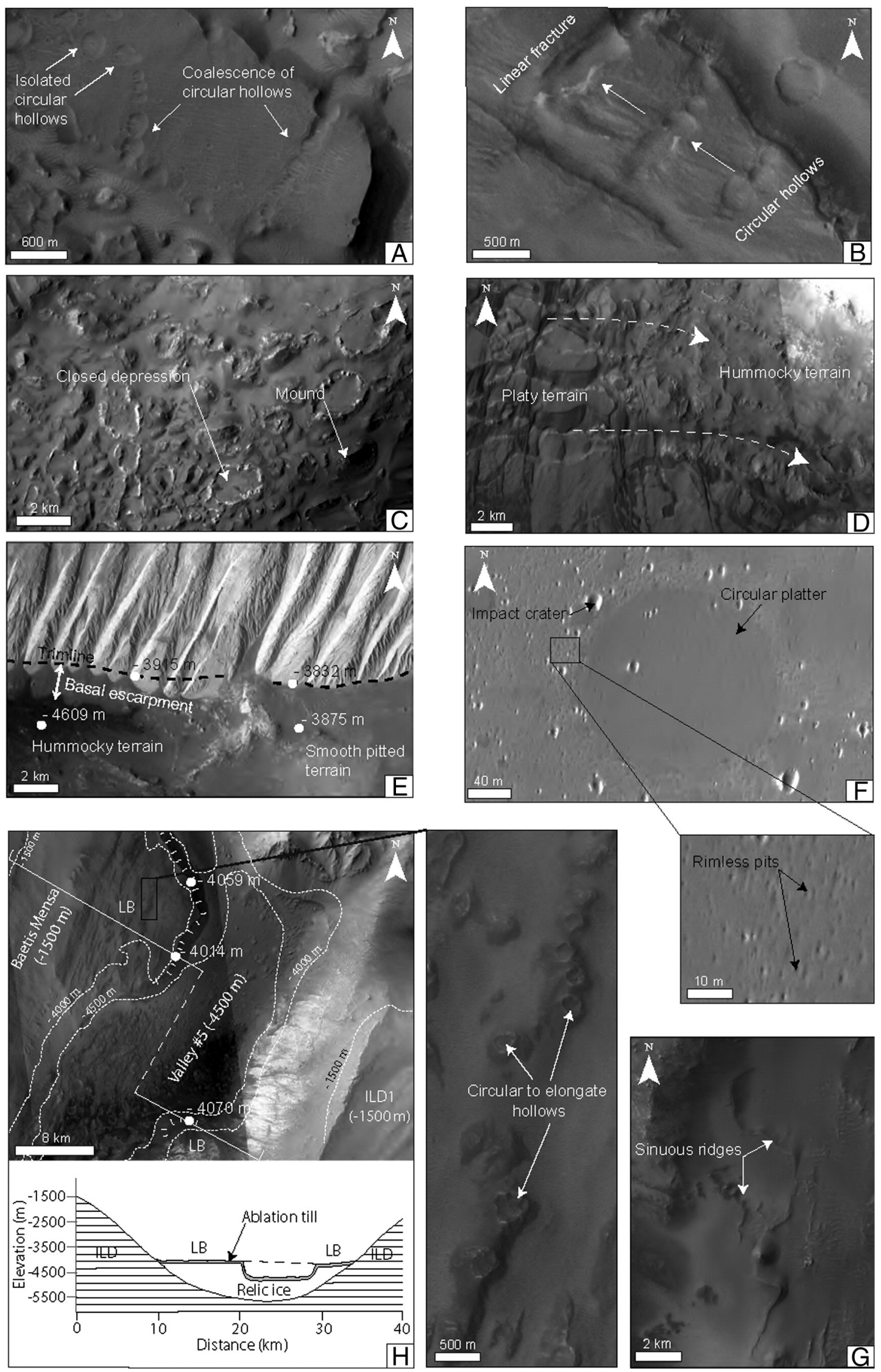

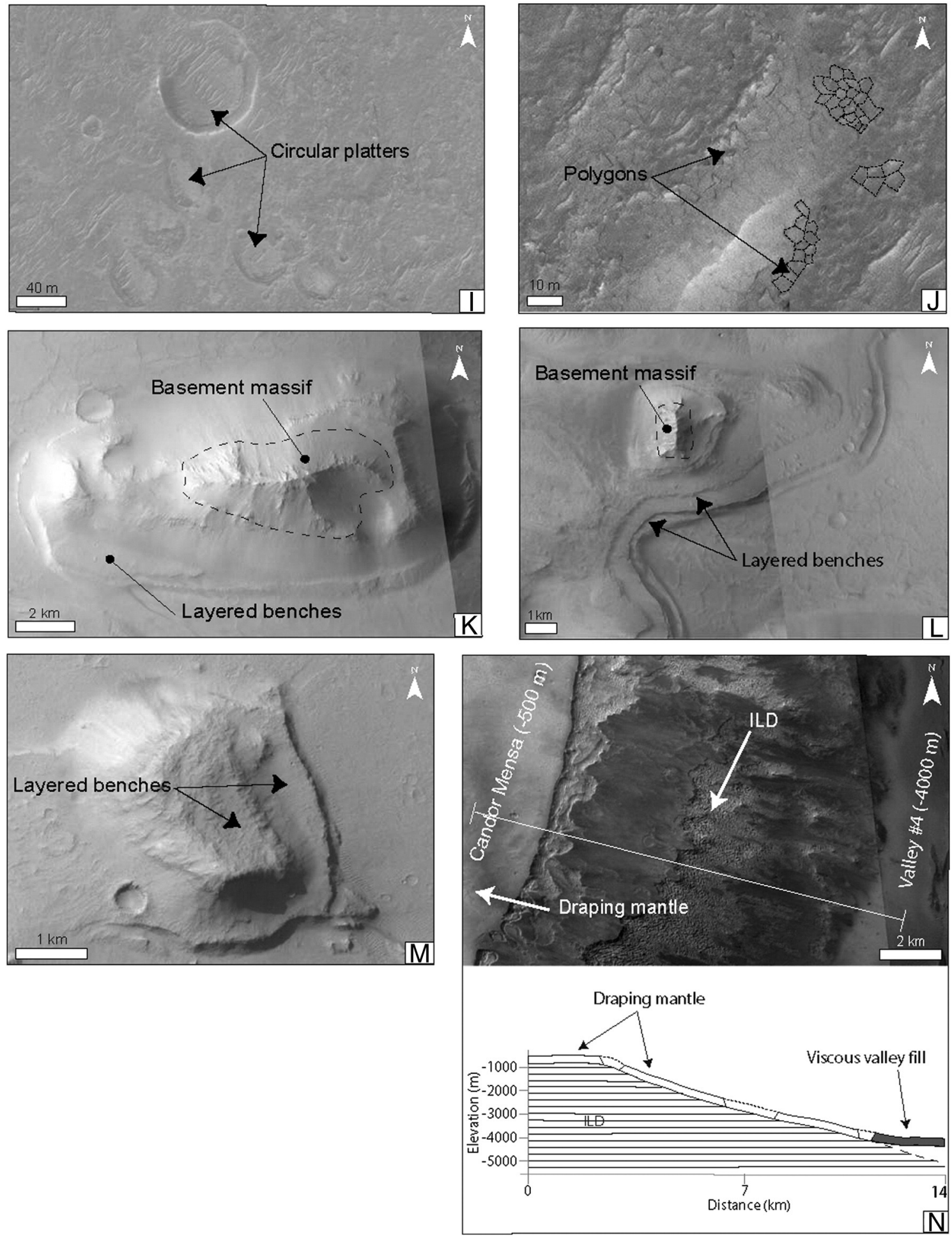

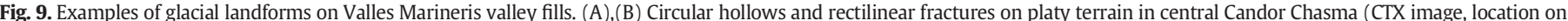

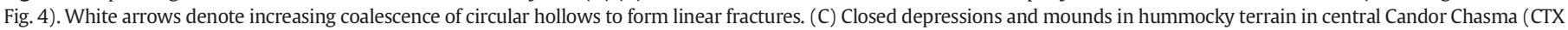

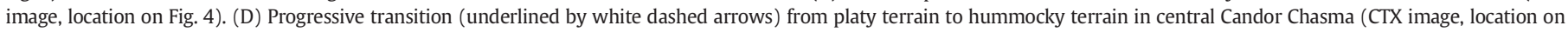

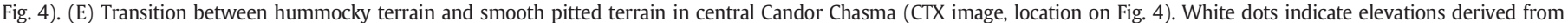

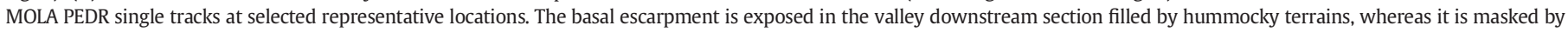

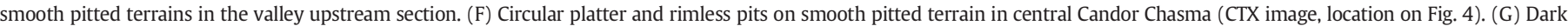

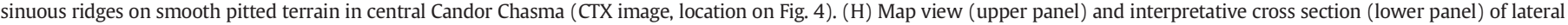

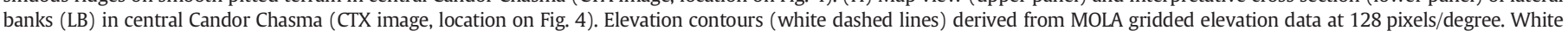

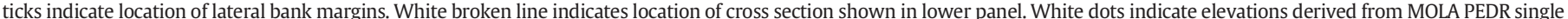

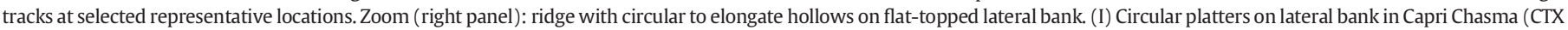

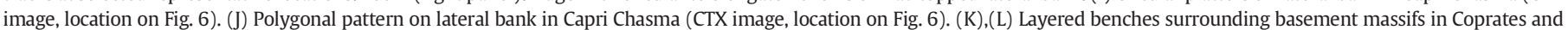

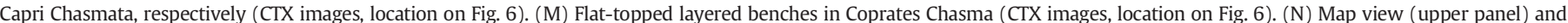

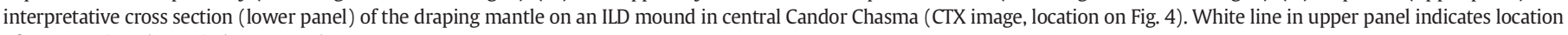
of cross section shown in lower panel. 

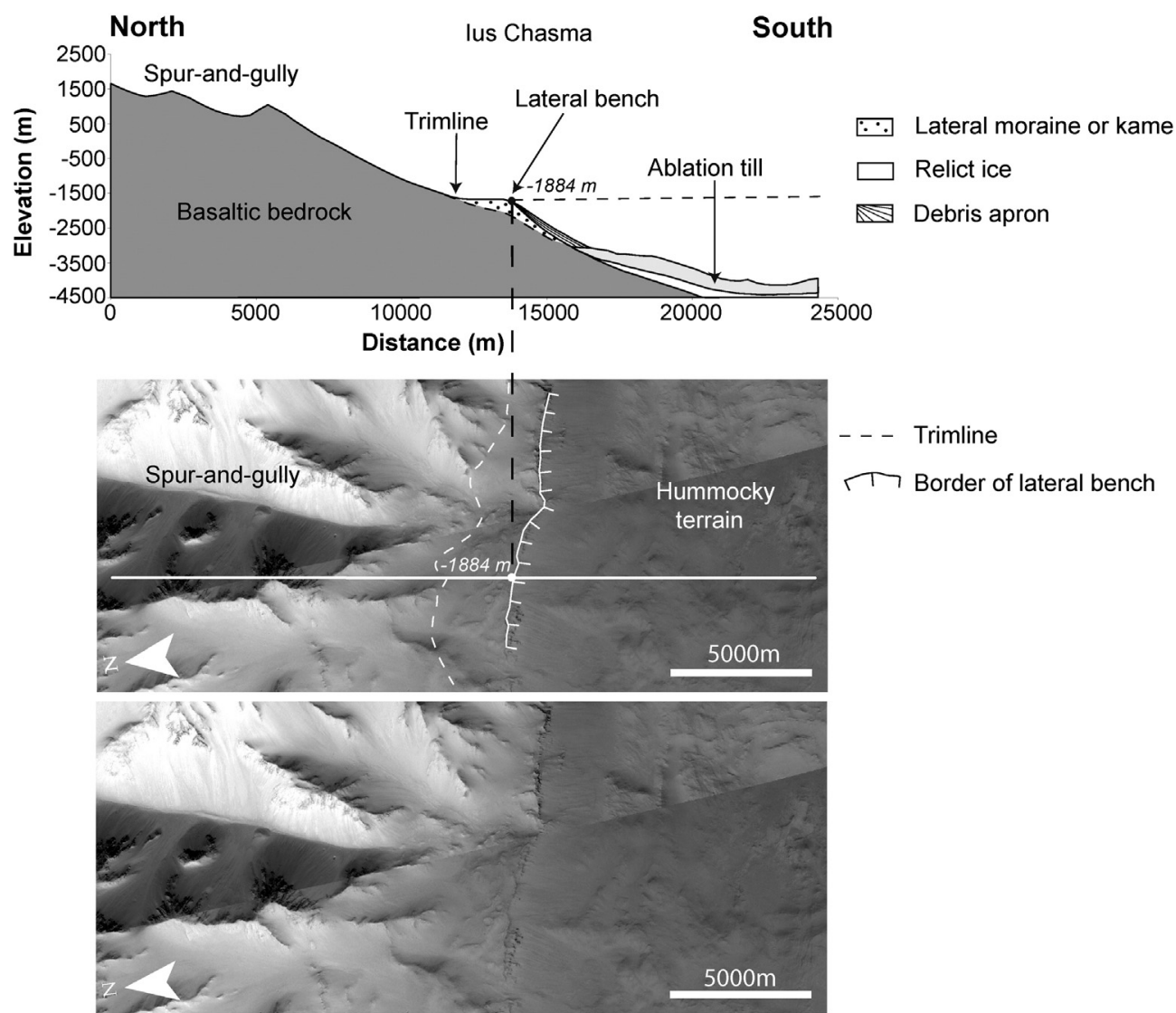

- - - Trimline

$\lceil$ Border of lateral bench

Fig. 10. Map view (CTX image, location on Fig. 2) and interpretative cross section of a lateral bench at the junction between valley wall and valley floor in northern Ius Chasma. White line in central panel indicates location of cross section shown in upper panel. Cross section based on elevation profile derived from MOLA PEDR single track.

\subsection{Lateral banks}

At several places in Valles Marineris, chasma walls are flanked by flat-topped lateral banks. In central Candor Chasma, for instance, valley \#5 is flanked on its western and eastern sides by lateral banks (Figs. 4, 5, and $9 \mathrm{H}$ ). These banks respectively extend over 17 and $3 \mathrm{~km}$ along the valley, for a width of 10 and $1 \mathrm{~km}$. They are bounded by steep, 400-m-high cliffs, and their flat surface lies at the same elevation as the trimline $(-4000 \mathrm{~m})$. Similar observations are made along the northwestern wall of Capri Chasma (Figs. 6 and 7). Above that lateral bank, the basement wallrock displays a spur-and-gully morphology and the smooth basal escarpment is not exposed. This configuration is consistent with the interpretation that the lateral bank is an erosional relict of an ancient sedimentary fill that covered the whole region up to the trimline and still masks the smooth basal escarpment in the places where it has been preserved (Fig. 9H).

These lateral banks were previously interpreted as sedimentary layers or erosional terraces of lacustrine origin (Harrison and Chapman, 2008). Here we suggest a glacial interpretation, based on the fact that they stand at the same elevation as the trimline. This interpretation is supported by their surface morphology. The surface of the lateral banks is smooth and is partially covered by a layer of dark sediment. In valley \#5 (central Candor Chasma), this surface is dotted with circular to elongate hollows with a diameter ranging from a few hundred meters to $2 \mathrm{~km}$ (Figs. 4, 5, and 9H). Some of these hollows have coalesced and are organized in rows parallel to the general direction of the valley. Similarly to hollows on platy terrains (Section 4.1) and on hummocky terrains (Section 4.2), hollows on lateral banks may be interpreted as ice disintegration landforms. Their alignment parallel to valley walls is consistent with their forming preferentially along preexisting englacial structures such as longitudinal shear zones, crevasses, or englacial morainic septa.

In Capri Chasma, the surface of the lateral bank is dotted with impact craters with erased or degraded rims and with filled central depressions (Fig. 9I). These are similar in morphology to platters formed by degradation of impact craters at the surface of the North Polar Cap (Banks et al., 2010). The lateral bank surface also displays polygon networks, several meters in diameter (Fig. 9J). Polygonal terrains have been found on Mars at all latitudes (Mangold, 2005; Levy et al., 2009), including regions close to the equator (Page, 2007; Balme and Gallagher, 2009). Many processes can lead to the development of polygonal terrains, with the main processes on Mars being thought to be thermal contraction and sublimation of ice-rich terrains (Head et al., 2003; Mangold, 2005; Marchant and Head, 2007; Lefort et al., 2009; Mangold, 2011a, b; Séjourné et al., 2011). Thus the presence of coalescent circular hollows organized in rows, of platters resembling degraded impact craters in icy materials, and of polygonal terrains at the surface of lateral banks is consistent with the interpretation that they are debris-covered erosional relicts of a glacial body that once filled central Candor Chasma, eastern Coprates Chasma, and western Capri Chasma up to the trimline.

\subsection{Layered benches}

Smooth layered benches, partly covered by darker sediments, are exposed on the floors and along the flanks of some Valles Marineris valleys (Harrison and Chapman, 2008). At the junction between Coprates Chasma and Capri Chasma for instance, some of these layered benches flank isolated basement massifs that project above chasma floors (Fig. 9K,L); their elevation is equal to that of the trimline (Figs. 6, 7, and 12). Other benches are smooth and flat-topped mounds 
A

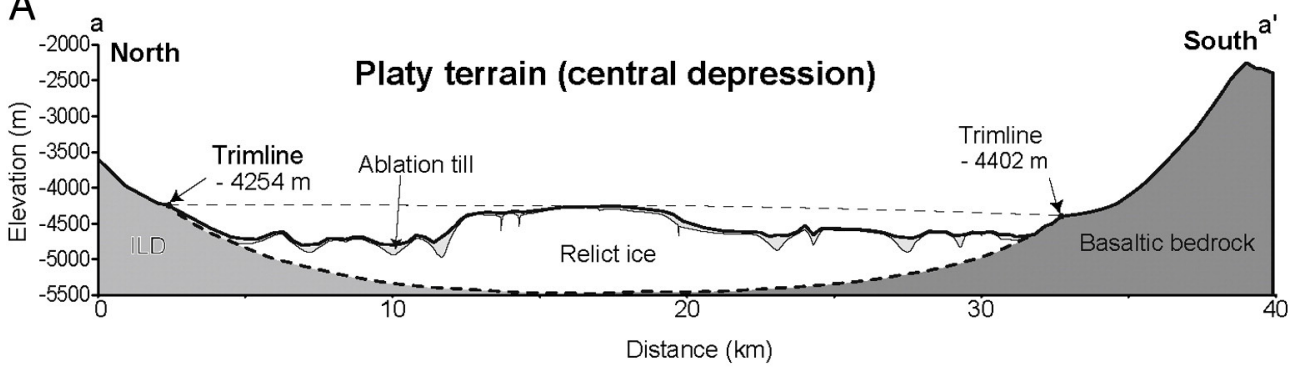

B
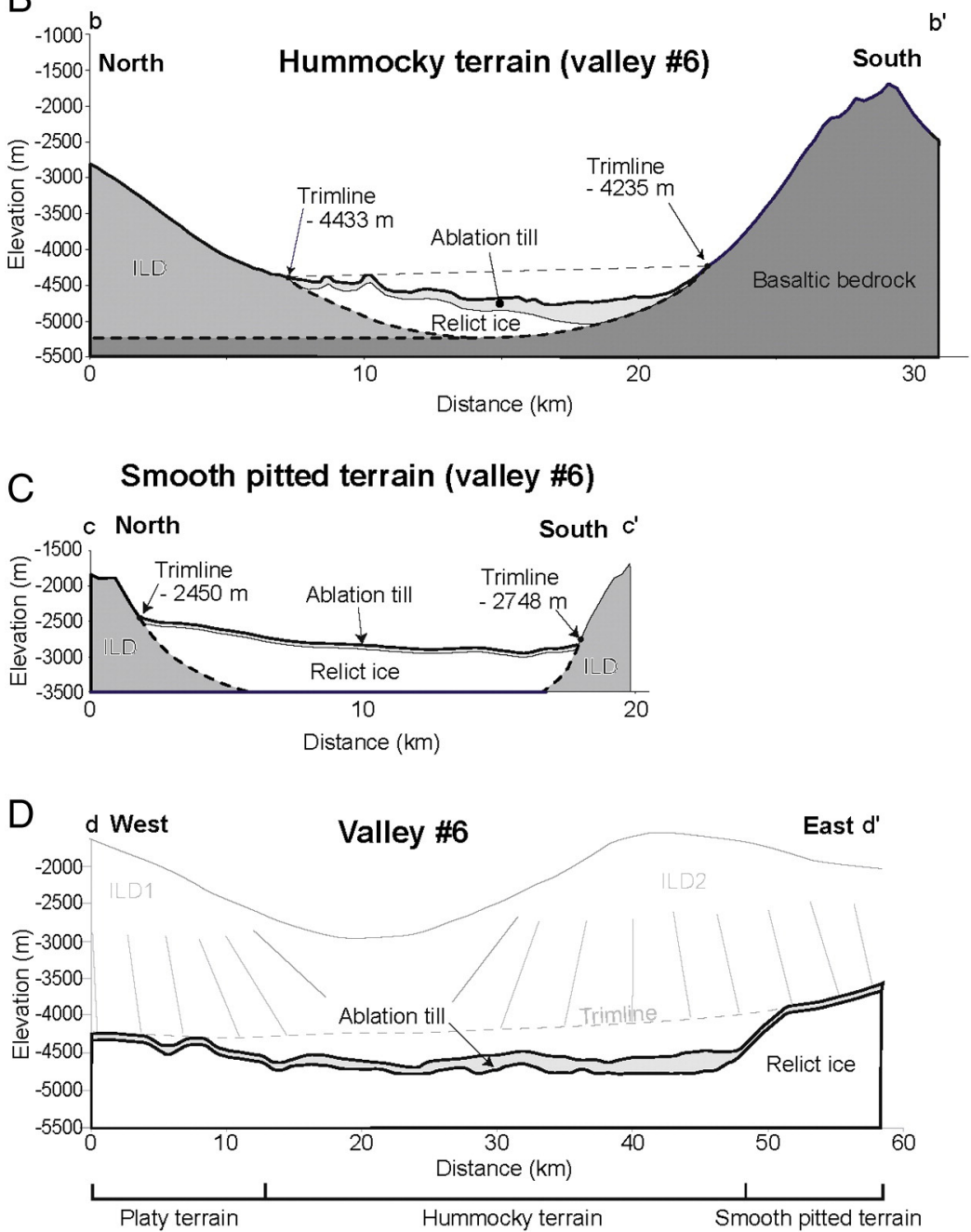

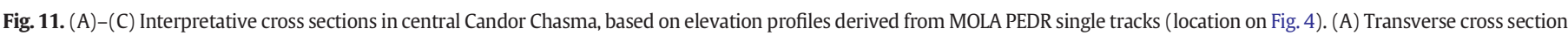

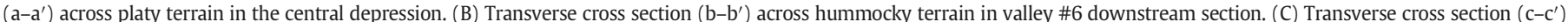

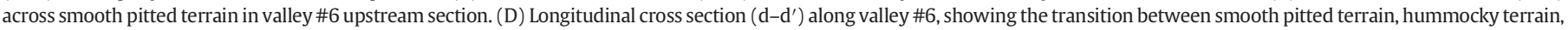
and platy terrain. Trimline and spur-and-gully morphology on southern flank of ILD 1 and ILD 2 mounds shown as gray sketch in the background.

scattered on chasma floors (Fig. 9M); these never exceed the trimline in elevation (Figs. 6, 7, and 12). The layering of these benches and their altimetric relationship with the trimline suggest that they are erosional relicts of an ancient sedimentary fill (Figs. 7D and 12).

These benches have been interpreted as relicts of lacustrine sedimentary accumulations (Harrison and Chapman, 2008). However, on the basis of their altitudinal relationship with the trimline and by analogy with lateral banks described in Section 4.4, we rather interpret these layered benches as debris-covered relict patches of an ancient glacier that once covered chasma floors up to the trimline. Moreover, these layered benches have a stair-step morphology on their flanks
(Fig. 9L), which is consistent with the stair-step morphology of mixed ice and dust layers as observed on the present-day Martian polar caps (Howard et al., 1982; Milkovich and Head, 2005; Banks et al., 2010). If this interpretation is correct, basement massifs that project above chasma floors stood as nunataks above the ice surface because they have higher elevations than the interpreted trimline (Fig. 12).

\subsection{Draping mantle}

Tops and flanks of some ILD mounds in Valles Marineris are covered by a smooth draping mantle about $100 \mathrm{~m}$ thick, partly degraded, and 


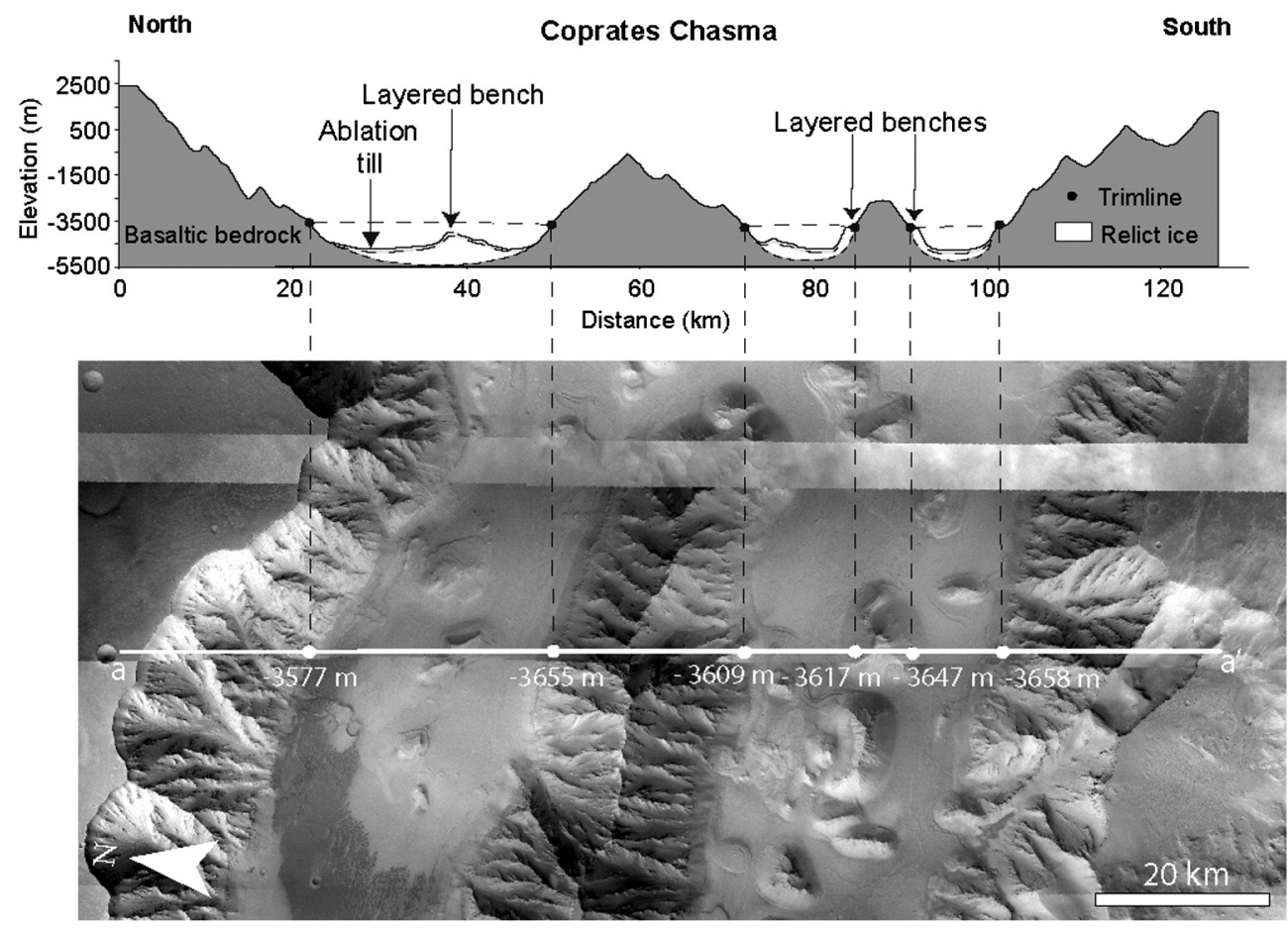

Fig. 12. Interpretative cross section across eastern Coprates Chasma, based on elevation profile derived from MOLA PEDR single track (location on Fig. 6).

locally overlain by a thin cover of dark aeolian deposits (Fig. 9N). This mantle has been particularly well preserved on ILD mounds in central Candor Chasma (Candor Mensa, Baetis Mensa, ILD1, and ILD2; Fig. 5). North of the central depression, it drapes the topographic surface from the top of Candor Mensa, down its eastern flank, across valley \#4, and up to the top of Baetis Mensa. Materials composing the bulk of ILD mounds are exposed only in windows opened by erosion through this draping mantle (Fig. 9N). Down the flanks of ILD mounds, the draping mantle merges progressively with the smooth pitted terrain that fills the upstream sections of valleys \#4, 5, and 6 (Fig. 5).

As already noticed by Le Deit et al. (2008) in eastern Candor Chasma, the draping nature of this mantle and its regional continuity across ILD mounds and intervening valleys suggest that it was formed by atmospheric deposition on the topographic surface. It is dotted with disintegration pits similar to those described on the smooth pitted terrains (Section 4.3); its overall surface morphology resembles that of the latitude-dependent-mantle interpreted in other regions of Mars as a superficial layer of ice mixed with dust (Kreslavsky and Head, 2002; Head et al., 2003). Therefore, we interpret this draping mantle as a relict of a mixture of ice and dust that accumulated on the topographic surface from the atmosphere. Consistent with this interpretation is the fact that the draping mantle merges progressively with the smooth pitted terrain that cover valley floors, just as snow mantle draping mountain flanks gradually merge with valley glaciers on Earth.

\section{Spatial synthesis}

In central Candor Chasma, the four types of terrains covering valley floors are interpreted as relicts of a regional glacier system. Their cartographic and altitudinal relationships with one another and with the trimline are consistent with the interpretation that an ancient ice fill once covered all the central depression and its tributary valleys up to the trimline (Figs. 5 and 11). Advanced disintegration of this ice fill has exposed the glacially trimmed basal escarpment along some sections of valley walls, whereas relict debris-covered ice bodies have been preserved in other places. Different disintegration stages can be recognized in these terrains. Smooth pitted terrains represent the least advanced stage and are Martian equivalents of terrestrial glaciers covered by ablation tills (Section 4.3). Platy terrain corresponds to an intermediate stage characterized by the development of surface ablation hollows and by the fragmentation of the initial glacier into disconnected relict ice bodies (Section 4.1). Hummocky terrains correspond to the most advanced stage and are analogs of terrestrial ablation moraines (Section 4.2). Lateral banks are interpreted as debris-covered relicts of these ancient valley glaciers, preferentially preserved along valley walls because of enhanced supply of slope debris. Spatial and morphological relationships between valley floor terrains and the draping mantle on valley walls suggest that these ancient glaciers were fed, at least partially, by accumulation from the atmosphere of ice probably mixed with dust on top and on flanks of the neighboring topographic ridges.

In eastern Coprates Chasma and in Ius Chasma, lateral banks, layered benches, and hummocky terrains on valley floors are also interpreted as erosional relicts of regionally extensive valley glaciers (Figs. 10 and 12). Spatial and altitudinal relationships between these landforms, lateral benches, and the trimline are consistent with the interpretation that an extensive glacier system once covered the floor of eastern Coprates Chasma and Ius Chasma up to the trimline. Hanging valleys and truncated spurs suggest that this major glacial fill was partly fed by minor glaciers flowing down tributary valleys along chasma walls.

Alternative nonglacial interpretations may be tentatively proposed for the individual significance of each landform described here (e.g., Lucchitta, 1999; Harrison and Chapman, 2008). However, a glacial interpretation is supported by the fact that these individual landforms collectively compose a self-consistent assemblage, similar in many respects to terrestrial glaciated valley landsystems (Benn and Evans, 1998; Evans, 2005). The trimline is currently not continuously visible along Valles Marineris wallslopes however (Fig. 13). This discontinuity may be due to spatial differences in the effectiveness of glacial erosion during the glaciation (Ballantyne and Harris, 1994), but it is most readily attributable to local degradation or covering by erosion, downslope postglacial mass movements, and sedimentation (Mège and Bourgeois, 2011).

The trimline decreases in elevation from - $1900 \mathrm{~m}$ in Ius Chasma to $-4000 \mathrm{~m}$ at the junction of Coprates Chasma with Capri Chasma. 


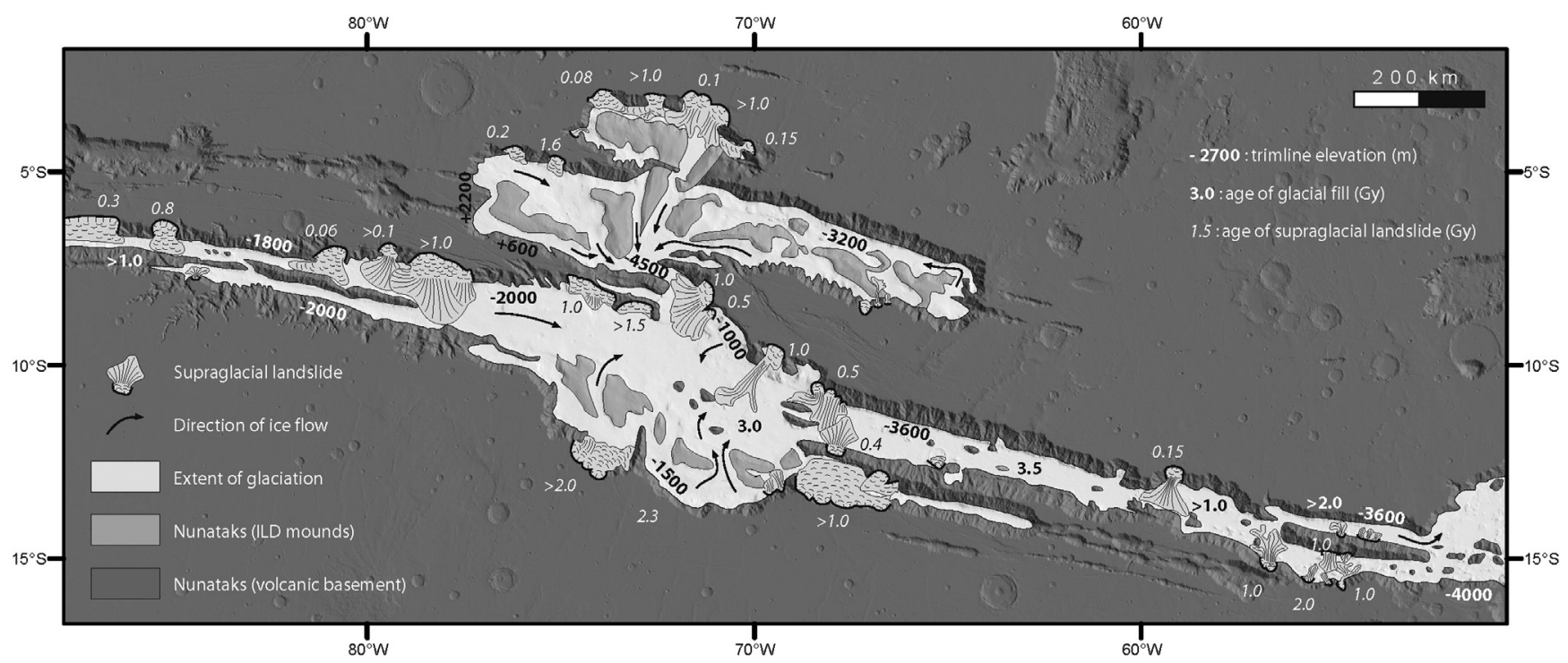

Fig. 13. Proposed extent of glaciation and location of supraglacial landslides in Valles Marineris.

The elevation of the Valles Marineris chasma floors is systematically lower than these values, except for landslide aprons and basement ridges that stand above valley floors. Therefore, the relict glacial features described here are merely parts of a much more extensive glacial landsystem that covered a major fraction of Valles Marineris in the past (Fig. 13). The VF that cover most chasma floors between basement massifs and ILD mounds are debris-covered ice relicts inherited from this ancient glaciation.

\section{Discussion}

\subsection{Thickness and volume of initial and relict ice fill}

The minimal thickness of the initial ice fill can be computed by subtracting the current elevation of valley floors from the elevation of the trimline: it is about $2000 \mathrm{~m}$ in Ius Chasma, $700 \mathrm{~m}$ in central Candor Chasma, and $1000 \mathrm{~m}$ in eastern Coprates Chasma (Fig. 13). Assuming that all Valles Marineris chasmata were once glaciated, the total initial ice volume estimated from these thicknesses is more than $0.3 \cdot 10^{6} \mathrm{~km}^{3}$.

These are minimal thicknesses and volumes, however, because relict debris-covered glacial bodies (smooth pitted terrain, platy terrain, hummocky terrain, lateral banks, and layered benches) and postglacial deposits (landslide aprons) still mask actual chasma floors in many parts of Valles Marineris. If we assume that all Valles Marineris chasmata have a typical U-shaped glacial cross-sectional profile and that their actual floors are currently masked by glacial and postglacial deposits (Figs. 10, 11, and 12), the glaciers might have been initially thicker than $3000 \mathrm{~m}$ in Ius Chasma, $1000 \mathrm{~m}$ in central Candor Chasma, and $2000 \mathrm{~m}$ in Coprates Chasma. The corresponding initial ice volume for all Valles Marineris would have been more than $10^{6} \mathrm{~km}^{3}$, the major part of which still remains currently in the form of debris-covered glacial relicts on chasma floors.

For comparison, the Antarctic and Greenland ice sheets on Earth have volumes of $25.7 \cdot 10^{6}$ and $2.85 \cdot 10^{6} \mathrm{~km}^{3}$, respectively (Marshall, 2005). The present-day Martian North and South Polar Caps have volumes of $1.2 \cdot 10^{6}-1.7 \cdot 10^{6} \mathrm{~km}^{3}$ and $2 \cdot 10^{6}-3 \cdot 10^{6} \mathrm{~km}^{3}$, respectively (Smith et al., 1999), i.e., on the same order of magnitude as the initial ice volume inferred for the whole Valles Marineris glaciation. The glaciation envisioned here is thus not unrealistic with respect to the present-day amount of ice potentially available at the surface of Mars.

\subsection{Ice preservation}

Surface ice is currently not stable at the Martian equator (Fanale et al., 1986; Baker, 2001). However, field observations in ice disintegration landscapes on Earth and theoretical calculations demonstrate that mantling of relict ice bodies by debris layers as thin as a few decimeters is enough to significantly inhibit rates of ice disintegration by melting (Ostrem, 1959; Mattson et al., 1993) or by sublimation (Marchant et al., 2002; Kowalewski et al., 2006, 2011). The development of protecting ablation tills during the first stages of glacial disintegration can thus explain the preservation until the present day of huge volumes of ancient ice on Valles Marineris chasma floors, as it does at higher latitudes on Mars (Squyres, 1978, 1979; Shean et al., 2005; Milkovich et al., 2006; Holt et al., 2008). In addition, rock debris produced by periglacial weathering at high elevations along valley walls and around basement massifs can have accumulated on the ice surface during the glaciation and favored later preservation of stratified benches and lateral banks. Paraglacial mass movements also are able to provide a large amount of debris during deglaciation and thus contribute to ice preservation.

\subsection{Comparison with climate models}

The present-day climatic conditions do not allow significant accumulations of surface ice at low latitudes on Mars (Fanale et al., 1986; Baker, 2001). Theoretical computations on the stability of ice during past periods of higher obliquity however predict that surface ice accumulation areas may have shifted between high-, mid-, and lowlatitudes repeatedly during the Martian history (Jakosky and Carr, 1985). These predictions have been confirmed recently by a number of climate numerical simulations (Mischna et al., 2003; Forget et al., 2006; Madeleine et al., 2009; Wordsworth et al., 2013). Some of these simulations predict that net ice accumulation rates might have been higher than $20 \mathrm{~mm} / \mathrm{y}$ at places along the Martian equator, for Amazonian physical conditions based on the present-day composition of the atmosphere (Madeleine et al., 2009) and for other physical conditions that might have prevailed earlier (fainter young sun, denser $\mathrm{CO}^{2}$ atmosphere) (Wordsworth et al., 2013). These rates could lead to the formation of a regional glacial fill thicker than $1000 \mathrm{~m}$ in Valles Marineris, over a period corresponding to the present-day obliquity cycle ( $\sim 50,000$ Martian years). It is therefore not unreasonable to hypothesize that the full glacial thickness envisaged here in Valles 

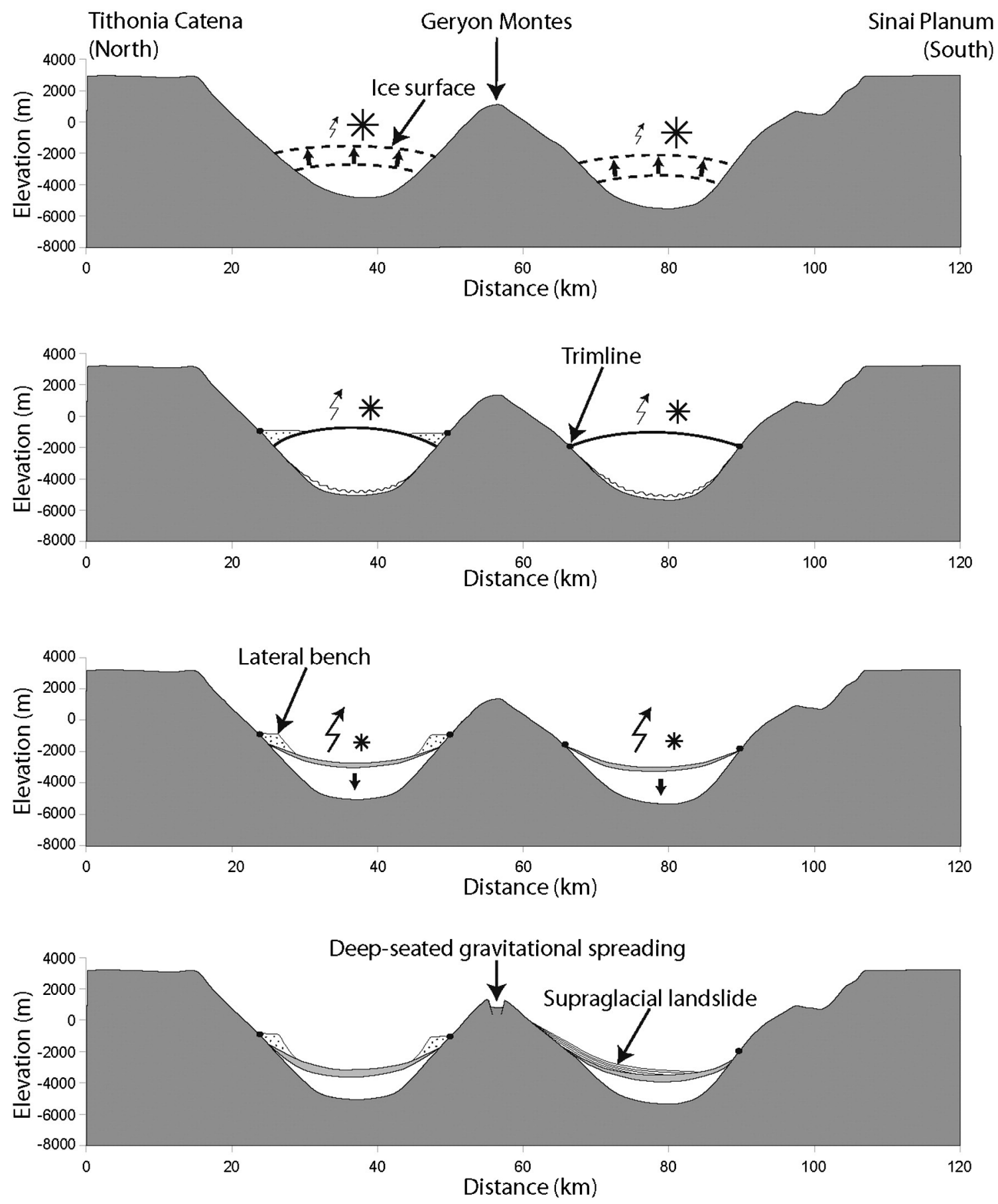

\begin{tabular}{|l|l}
\hline & Ice \\
\hline$\because \vdots \ldots$ & Lateral moraine or kame \\
\hline & Ablation till \\
\hline & Basaltic basement
\end{tabular}

* Ice accumulation
1 Ablation by sublimation
1 Ice thickness changes
들 Basal melting

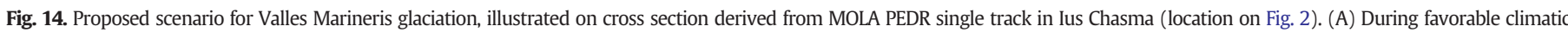

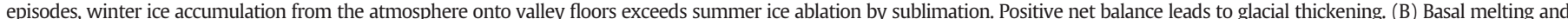

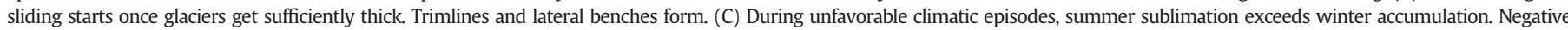

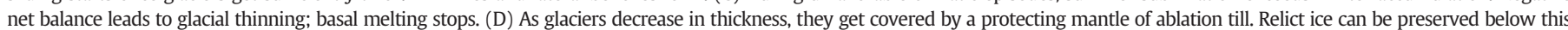

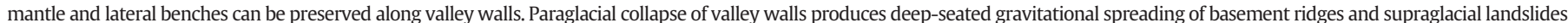

Marineris (1000 to $3000 \mathrm{~m}$ ) may possibly have accumulated over one obliquity cycle only. An alternative is that this huge ice thickness has resulted from successive accumulation episodes, smaller but repeated over numerous climatic cycles; this scenario implies that ice would have accumulated during favorable times and would have been protected from disintegration by superficial ablation tills or other 
kinds of sediments during unfavorable times (Ostrem, 1959; Mattson et al., 1993; Kowalewski et al., 2006, 2011).

\subsection{Glacial disintegration: melting or sublimation?}

If the landforms described here indeed are degraded relicts of a much more extensive glacial system, then a fraction of the ice that initially covered the Valles Marineris chasma floors has vanished by now. On Earth, glacier disintegration generally occurs by melting (Evans, 2005). But, under specific climatic conditions such as those of the Dry Valleys (Antarctica), the Kilimanjaro (equatorial Africa), or the Gurla Mandhata (Tibet), sublimation is the dominant glacial ablation process (Kuhle, 1999; Molg et al., 2003; Molg and Hardy, 2004; Molg et al., 2005; Cullen et al., 2006; Fountain et al., 2006; Cawkwell, 2007; Cullen et al., 2007; Hoffman et al., 2008; Molg et al., 2008).

Analyzing ice disintegration landforms can help assess whether Valles Marineris glaciers vanished mostly by melting or by sublimation. Terrestrial ablation moraines generally comprise hummocky terrains with mounds, doughnut-shaped features, kettle holes, and closed depressions, which are classically attributed to glacial disintegration by melting (Hambrey et al., 1997; Mollard, 2000; Boone and Eyles, 2001; Schomacker, 2008). Proglacial meltwater drainage channels are generally associated with these ablation moraines.

To our knowledge, there is so far no published description of kettle holes, doughnut-shaped features, or closed depressions on ablation moraines produced by sublimation on Earth. This does not preclude the production of similar landforms by sublimation on Mars, as is exemplified by a wide range of closed scalloped or lobate depressions that have been attributed to ice sublimation in other regions of Mars and on other planetary bodies (Costard and Kargel, 1995; Thomas et al., 2000; Kreslavsky and Head, 2002; Head et al., 2003; Morgenstern et al., 2007; Kadish et al., 2008; Lefort et al., 2009; Le Deit et al., 2010; Mangold, 2011a,b; Séjourné et al., 2011; Soare et al., 2012). Terrestrial examples of sublimation landforms comprising closed depressions and mounds can be found at the surface of glaciers that currently disintegrate dominantly by sublimation on top of Kilimanjaro, in the Dry Valleys, and on the flanks of the Gurla Mandhata. These glacial disintegration landforms are not associated with proglacial meltwater drainage channels. Because no meltwater drainage channel is associated with the various terrains interpreted here as having formed by glacial disintegration in Valles Marineris, we infer that the Valles Marineris glacial system most likely disintegrated by sublimation.

This inference is supported by the fact that most terrains interpreted here as debris-covered relict ice bodies (smooth pitted terrains, platy terrains, lateral banks, layered benches) have flat tops but steep walls. On Earth, steep ice walls are diagnostic features of glaciers where ablation occurs dominantly by sublimation (Kuhle, 1999; Molg et al., 2003; Molg and Hardy, 2004; Molg et al., 2005; Cullen et al., 2006; Fountain et al., 2006; Cawkwell, 2007; Cullen et al., 2007; Hoffman et al., 2008; Molg et al., 2008). To our knowledge, there is no terrestrial example of glacial disintegration landforms resembling the platy terrain of Valles Marineris, i.e., platy relict ice bodies separated from each other by networks of interconnected rectilinear fractures with steep-sided walls. This difference also supports the idea that glacial disintegration in Valles Marineris mostly occurred by sublimation, whereas it generally results from melting on Earth.

\subsection{Bottom-to-top glacial development scheme}

When compared to terrestrial valley glaciers, the Valles Marineris glacial landsystem displays two striking specificities at least. First, on Earth, extensional strain between the moving glacier ice and the relatively immobile ice adhering to valley walls generate a specific kind of crevasse, known as rimayes (or bergschrunds) at heads and along flanks of most valley glaciers (Benn and Evans, 1998). In Valles Marineris, we could find no clear evidence of such crevasses at the contact between relict glacial fills and valley walls. This apparent lack of rimayes may be attributed to late mechanical closing or late sedimentary filling. Alternatively, glaciers in Valles Marineris might have lacked rimayes originally because there was no extensional strain between chasma glacial fills and their walls.

The later interpretation requires that glacial flow dynamics in Valles Marineris differed in some way from those of terrestrial glaciers. This idea is supported by the second specificity of the Valles Marineris glacial landsystem. In most terrestrial glaciated valley landsystems, ice forms in response to net annual snow accumulation in upstream catchment basins comprising elevated plateaus, mountain flanks, and high elevation interconnected networks of tributary valleys and cirques. The ice flows downstream along these networks, feeds larger outlet glaciers and eventually melts when it reaches areas dominated by net annual ablation at lower elevations (Benn and Evans, 1998). This can be summarized as a top-to-bottom glacial development scheme.

At odds with this classical scheme, there is no clear evidence for the former existence of well-developed upstream glacial catchment basins in Valles Marineris. Hanging valleys along chasma walls seldom define interconnected networks and, when compared to terrestrial glacial catchment basins, their volume is apparently too small to feed glacial deposits as thick as several hundred meters on chasma floors. We could find clear morphological evidence neither of a possible glacial connection between the chasma floors and the surrounding plateaus nor of massive glaciations on these plateaus. Mineralogical interpretations of spectroscopic data suggest that the plateaus remained exposed to subaerial pedogenic weathering through the major part of their history, except perhaps for a thin and widespread mantle of layered deposits interpreted as a former mixture of ice and silicate particles accumulated from the atmosphere (Le Deit et al., 2010, 2012).

Under these conditions, it is difficult to assume that the Valles Marineris glaciated valley landsystem developed according to the classical top-to-bottom scheme. A reasonable and attractive hypothesis is that it was rather controlled by a bottom-to-top scheme, with net annual accumulation occurring mostly at lower elevations (chasma floors) and net annual ablation occurring mostly at higher elevations (top of chasma walls). Ice thus would have accumulated directly from the atmosphere onto chasma floors, with minor contributions from tributary glaciers flowing down hanging valleys.

A bottom-to-top development scheme for the Valles Marineris glacial landsystem is consistent with the expectation that net annual accumulation rates generally decrease with elevation on Mars, whereas they generally increase with elevation on Earth (Fastook et al., 2008). It is consistent also with the fact that, except for the two polar caps, present-day glaciers on Mars have been observed on crater floors only (Conway et al., 2012) and that evidence for ancient glaciations has been found in Mars's two deepest impact basins, Argyre and Hellas (Kargel and Strom, 1992).

\subsection{Flow pattern}

The presence of a glacially trimmed surface at the base of valley walls, of viscously deformed ridges on valley floors, and of fracture patterns similar to crevasse networks of terrestrial outlet glaciers in the Candor Chasma central depression, suggests that the glaciers in Valles Marineris were able to flow at some time of their history. The flow of glaciers is controlled by their surface slope gradient (Benn and Evans, 1998). On this basis, long-wavelength differences in elevation of the interpreted trimline ( -1900 to $-2000 \mathrm{~m}$ in Ius Chasma, -3600 to $-4000 \mathrm{~m}$ in Coprates Chasma; Fig. 13) indicate that glacial flow was generally from the western to the eastern part of the Ius ChasmaMelas Chasma-Coprates Chasma system.

In central Candor Chasma, variations in elevation of the trimline suggest that glaciers flowed toward the Candor Chasma central depression, down valleys \#2 and \#3 from the west (west Candor Chasma), down valleys \#4 and \#5 from the north (Ophir Chasma), and down valleys \#6 and \#7 from the east (east Candor Chasma) (Figs. 4, 5, and 13). At 
the present-day, the floor of valley \#1 (Melas Labes) forms a topographic saddle between the Candor Chasma central depression and Melas Chasma (Fig. 1). The saddle is higher in elevation $(-2500 \mathrm{~m})$ than the trimline observed in the Candor Chasma central depression $(-4500 \mathrm{~m})$. It is basically a pile of stacked landslide aprons from surrounding chasma walls (Quantin et al., 2004a, 2004b). These landslide aprons have unexpectedly long runout distances and cover unexpectedly large surfaces (Quantin et al., 2004a, 2004b; Lucas and Mangeney, 2007). They also display longitudinal ridges and furrows, which is a classical morphological signature of landslide emplacement on glaciers (Lucchitta, 1978; Shaller and Komatsu, 1994; De Blasio, 2011). These characteristics are consistent with the assumption that a relict glacial fill is currently buried below the stack of landslide aprons. Hence the northern (Candor Chasma-Ophir Chasma) and southern (Ius ChasmaMelas Chasma-Coprates Chasma) glacial systems were most probably connected across Melas Labes valley.

\subsection{Basal thermal regime}

All past glacial landsystems that have been recognized so far at Martian low latitudes have been interpreted as cold-based (Head and Marchant, 2003; Head et al., 2005; Head and Marchant, 2006; Head et al., 2006a,b; Dickson et al., 2008; Holt et al., 2008; Head et al., 2010). Because they are unable to slide over their beds, cold-based glaciers are inefficient in eroding their basements; thus they generally have a protective role and preserve pre-glacial landscapes (Sugden et al., 1995; Benn and Evans, 1998; Cuffey et al., 2000; Sugden et al., 2005). On the other hand, the development of glacially trimmed escarpments, as spectacular as those visible at the base of Valles Marineris chasma walls, requires vigorous basal sliding; hence the existence of significant amounts of liquid water on the glacial bed. This evidence alone is sufficient to infer that the Valles Marineris glacial system was warm-based, at some time of its history and in some places at least. This is consistent with theoretical estimations and numerical simulations based on reasonable values for surface temperatures (210-230 K) and geothermal heat fluxes $\left(0.05\right.$ to $\left.0.15 \mathrm{~W} / \mathrm{m}^{2}\right)$, which indicate that the pressure melting point could be reached in the past on Mars at ice depths of a few hundred meters (Carr and Head, 2003; Fastook et al., 2012). It is also consistent with the existence of landforms interpreted as eskers and attributed to ancient wet-based glaciations at higher latitudes (Kargel and Strom, 1992).

\subsection{Possible link with outflow channels}

A number of outflow channels (Simud, Tiu) are connected to the eastern tip of Valles Marineris. These outflow channels are believed to have been carved by catastrophic water floods. The origin of water for these floods is still debated (e.g., Baker, 2001). It has been suggested that spillover of a lake system in eastern Valles Marineris could have provided water necessary for these floods (Warner et al., 2013). Alternatively, this water could have been provided by basal melting associated with the wet-based glacial landsystem described here. On the basis of geomorphological features observed within these outflow channels, Lucchitta (1982) suggested that ice may have occupied some outflow channels at some time. This might have happened during a major readvance of glaciers extending from Valles Marineris.

\subsection{Paraglacial and supraglacial collapse of valley walls}

Many volcanic basement ridges that separate Valles Marineris valleys from one another display crestal grabens at their tops, uphill-facing normal fault scarps along their flanks, and folded strata at their base. By analogy with terrestrial deep-seated gravitational ridge spreading analogues, this remarkable tectonic assemblage has been attributed to gravitational readjustment of basement ridges after deglaciation of the intervening valleys (Mège and Bourgeois, 2011). The ubiquitous distribution of these paraglacial gravitational features is consistent with the existence of an extensive valley glacier system in Valles Marineris.

Many parts of Valles Marineris chasma floors are covered by landslide deposits. The dynamics of these landslides remain controversial, mostly because their debris aprons have singular morphologies, unexpectedly long runout distances, and cover unexpectedly wide areas, comprised in the range between those of dry subaerial landslides and those of wet submarine landslides (Lucchitta, 1979; Quantin et al., 2004a, 2004b; Lucas and Mangeney, 2007). Interestingly, some studies noted the morphological similarities of Martian landslides and landslides occurring on terrestrial glaciers (Lucchitta, 1978, 1979; Shaller and Komatsu, 1994; De Blasio, 2011). In particular, they had pointed out that landslide aprons in Valles Marineris have striking morphological similarities with landslide aprons on terrestrial glaciers such as the Sherman and Black Rapids glaciers in Alaska (Shugar and Clague, 2011). These morphological similarities include uncommonly long runout distances, tongue-like shapes, tendency to spread over vast areas, and the presence of longitudinal ridges and furrows. Extensive glaciation thus provides an attractive explanation for the existence of landslide aprons displaying these morphological characteristics in Valles Marineris. Following our interpretations, they have been emplaced supraglacially, either on actively flowing glaciers when Valles Marineris was entirely glaciated, or at the surface of debris-covered relict ice bodies later. If they had been emplaced over actively flowing glaciers, they would have been displaced and deformed by ice flow. Instead, considering their morphology, particularly in regard with their intact longitudinal ridges, furrows, and overlapping relationships, landslides do not appear to be subjected to post-formation modifications. Therefore the currently visible landslide aprons were emplaced once glacial flow had come to an end. There is no observational evidence of significant horizontal debris apron displacement that could be attributed to underlying actively flowing glaciers. Debris motion over glaciers could be one of the factors that explain the very low friction angle calculated by Lucas et al. (2011) for the Valles Marineris landslides. This supports the interpretation that some of the biggest landslides in Valles Marineris derive from an advanced stage of paraglacial, deep-seated gravitational ridge spreading (Mège and Bourgeois, 2011).

\subsection{Age of glaciation and corresponding climate}

The development of the Valles Marineris glacial system is younger than the formation of the chasma network, which has been attributed to a combination of extension and collapse during the late Noachian to early Hesperian (Andrews-Hanna, 2011a,b,c). However, it is older than landslide aprons emplaced on the smooth basal escarpment along chasma walls and on relict ice bodies inherited from the glaciation on the chasma floors. It is also older than landslide scars that cut across spurs and gullies in the upper part of valley walls (Lucchitta, 1979). Crater counts and morphological analyses on landslide aprons demonstrate that these landslides occurred continuously from the NoachianHesperian boundary (3.5 Gy) to the present-day and had the same dynamics throughout this time interval (Quantin et al., 2004a, 2004b). Therefore, the glaciation of Valles Marineris dates back from times as old as the late Noachian to early Hesperian.

Numerical climate simulations based on current atmospheric characteristics predict massive accumulations of ice at the Martian equator in response to orbital changes (Madeleine et al., 2009). Therefore, extensive glaciation in Valles Marineris during the late Noachian to early Hesperian apparently does not require that the atmosphere at that time was significantly different from the current one. Orbital changes in the ancient history of Mars (Laskar et al., 2004) might have provided the necessary climatic conditions to allow equatorial glaciations with current-like atmospheric characteristics. However, if Martian orbital cycles on their own are enough to explain glaciations within Valles Marineris, then glaciations should have occurred repeatedly since the Noachian-Hesperian 
period. In that case, the relatively pristine appearance of landslides in Valles Marineris indicates that post-landslide glaciers were cold-based. Alternatively, the development of the pre-landslide, wet-based Valles Marineris glacial system has perhaps required not only the obliquity cycle, but also some additional factors (fainter younger sun, denser $\mathrm{CO}^{2}$ atmosphere) (Wordsworth et al., 2013).

\section{Conclusion}

Self-consistent landform assemblages indicate that Valles Marineris, the giant valley system that stretches along the Martian equator, was entirely glaciated during late Noachian to early Hesperian times and still contains huge volumes of fossil ice inherited from this ancient glaciation. Alternative nonglacial interpretations may be tentatively proposed for the individual significance of each landform described here. However, a glacial interpretation is supported by the fact that these individual landforms collectively compose an elegant and selfconsistent assemblage typical of a relict glaciated valley landsystem. Fig. 13 shows our favored scenario for the history of this glacial fill.

The Valles Marineris glacial system comprised wet-based glaciers that were able to flow and slide over their beds at some time of their history at least. It was most probably fed by ice accumulating at low elevations directly from the atmosphere onto chasma floors and valley walls, with only minor contributions from tributary glaciers flowing down from higher elevations. Similar fossil glacial landsystems dating back from the early Martian history are to be expected in many other low-latitude troughs such as chasmata, chaos, valleys, impact craters, and other basins.

\section{Acknowledgments}

This work benefited from financial support of Centre National de la Recherche Scientifique (CNRS), Institut National des Sciences de l'Univers (INSU), Programme National de Planétologie (PNP), Agence Nationale de la Recherche (Project ANR-08-JCJC-0126 MADMACS), Centre National d'Études Spatiales (CNES) and Observatoire des Sciences de l'Univers Nantes Atlantique (OSUNA). M. Gourronc is supported by a Ph.D. research grant from the French Ministère de l'Enseignement Supérieur et de la Recherche (MESR). Marion Massé and Daniel Mège are supported by Grant FNP TEAM/2011-7/9 from the Foundation for Polish Science. We thank Goro Komatsu for his positive and constructive review of a preliminary version of the manuscript.

\section{References}

Andrews-Hanna, J.C., 2012a. The formation of Valles Marineris: 1. Tectonic architecture and the relative roles of extension and subsidence. J. Geophys. Res. 117, E03006 http://dx.doi.org/10.1029/2011JE003953.

Andrews-Hanna, J.C., 2012b. The formation of Valles Marineris: 2. Stress focusing along the buried dichotomy boundary. J. Geophys. Res. 117, E04009. http://dx.doi.org/10.1029/ 2011JE003954.

Andrews-Hanna, J.C., 2012c. The formation of Valles Marineris: 3. Trough formation through super-isostasy, stress, sedimentation, and subsidence. J. Geophys. Res. 117, E06002. http://dx.doi.org/10.1029/2012JE004059.

Armstrong, J.C., Titus, T.N., Kieffer, H.H., 2005. Evidence for subsurface water ice in Korolev crater, Mars. Icarus 174, 360-372.

Baker, V.R., 2001. Water and the Martian landscape. Nature 412, 228-236.

Ballantyne, C.K., Harris, C., 1994. The Periglaciation of Great Britain. Cambridge Univ Press, Cambridge, UK (330 pp.)

Balme, M.R., Gallagher, C., 2009. An equatorial periglacial landscape on Mars. Earth Planet. Sci. Lett. 285, 1-15.

Banks, M.E., Byrne, S., Galla, K., McEwen, A.S., Bray, V.J., Dundas, C.M., Fishbaugh, K.E., Herkenhoff, K.E., Murray, B.C., 2010. Crater population and resurfacing of the Martian north polar layered deposits. J. Geophys. Res. 115, E08006. http://dx.doi.org/10.1029/ 2009JE003523.

Benn, D.I., Evans, D.J.A., 1998. Glaciers and Glaciation. Edward Arnold, London (734 pp.).

Blasius, K.R., Cutts, J.A., Guest, J.E., Masursky, H., 1977. Geology of the Valles Marineris: first analysis of imaging from the Viking 1 Orbiter primary mission. J. Geophys. Res. $82,4067-4091$

Boone, S.J., Eyles, N., 2001. Geotechnical model for great plains hummocky moraine formed by till deformation below stagnant ice. Geomorphology 38, 109-124.
Burr, D.M., Bruno, B.C., Lanagan, P.D., Glaze, L.S., Jaeger, W.L., Soare, R.J., Tseung, J., Skinner, J.A., Baloga, S.M., 2009. Mesoscale raised rim depressions (MRRDs) on Earth: a review of the characteristics, processes, and spatial distributions of analogs for Mars. Planet. Space Sci. 57, 579-596.

Calvari, S., Pinkerton, H., 1998. Formation of lava tubes and extensive flow field during the 1991-93 eruption of Mount Etna. J. Geophys. Res. 103, 27291-27302.

Carr, M.H., Head, J.W., 2003. Basal melting of snow on early Mars: a possible origin of some valley networks. Geophys. Res. Lett. 30, 2245. http://dx.doi.org/10.1029/2003GL018575.

Cawkwell, F.G.L., 2007. The disappearing snows of Kilimanjaro: crossing the border of irreversible environmental change? Chimera 22, 125-139.

Chapman, G., Soderblom, L.A., Cushing, G., 2005. Evidence of very young glacial process in central Candor Chasma, Mars. Lunar Planet. Sci. 36 (Abstract 1850).

Chojnacki, M., Hynek, B.M., 2008. Geological context of water-altered minerals in Valles Marineris, Mars. J. Geophys. Res. 113, E12005. http://dx.doi.org/10.1029/2007JE003070.

Conway, S.J. Hovius, N., Barnie, T. Besserer, J., Le Mouélic, S., Orosei, R., Read, N.A, 2012. Climate-driven deposition of water ice and the formation of mounds in craters in Mars' north polar region. Icarus 220, 174-193.

Costard, F.M., Kargel, J.S., 1995. Outwash plains and thermokarst on Mars. Icarus 114, 93-112.

Cuffey, K.M., Conway, H., Gades, A.M., Hallet, B., Lorrain, R., Severinghaus, J.P., Steig, E.J., Vaughn, B., White, J.W.C., 2000. Entrainment at cold glacier beds. Geology 28, 351-354.

Cullen, N.J. Molg T., Kaser, G. Hussein, K. Steffen, K., Hardy, D.R., 2006. Kilimanjaro glaciers: recent areal extent from satellite data and new interpretation of observed 20th century retreat rates. Geophys. Res. Lett. 33, L16502. http://dx.doi.org/10.1029/ 2006GL027084.

Cullen, N.J., Molg, T., Kaser, G., Steffen, K., Hardy, D.R., 2007. Energy-balance model validation on the top of Kilimanjaro, Tanzania, using eddy covariance data. Ann. Glaciol. 46, 227-233.

De Blasio, F.V. 2011. Landslides in Valles Marineris (Mars): a possible role of basal lubrication by subsurface ice. Planet. Space Sci. 59, 1384-1392.

Dickson, J.L., Head, J.W., Marchant, D.R., 2008. Late Amazonian glaciation at the dichotomy boundary on Mars: evidence for glacial thickness maxima and multiple glacial phases. Geology 36, 411-414.

Dickson, J.L., Head, J.W., Marchant, D.R., 2010. Kilometer-thick ice accumulation and glaciation in the northern mid-latitudes of Mars: evidence for crater-filling events in the late Amazonian at the Phlegra Montes. Earth Planet. Sci. Lett. 294, 332-342.

Etzelmüller, B., 2000. Quantification of thermo-erosion in pro-glacial areas - examples from Svalbard. Z. Geomorphol. 44, 343-361.

Evans, D.J.A. (Ed.), 2005. Glacial Landsystems. Arnold, London (544 pp.).

Fanale, F.P., Salvail, J.R., Zent, A.P., Postawko, S.E., 1986. Global distribution and migration of subsurface ice on Mars. Icarus 67, 1-18.

Fastook, J.L., Head, J.W., Marchant, D.R., Forget, F., 2008. Tropical mountain glaciers on Mars: altitude-dependence of ice accumulation, accumulation conditions, formation times, glacier dynamics, and implications for planetary spin-axis/orbital history. Icarus 198, 305-317.

Fastook, J.L., Head, J.W., Marchant, D.R., Forget, F., Madeleine, J.-B., 2012. Early Mars climate near the Noachian-Hesperian boundary: independent evidence for cold conditions from basal melting of the south polar ice sheet (Dorsa Argentea Formation) and implications for valley network formation. Icarus 219, 25-40.

Fishbaugh, K.E., Head, J.W., 2001. Comparison of the north and south polar caps of Mars: new observations from MOLA data and discussion of some outstanding questions. Icarus 154, 145-161.

Flahaut, J., Quantin, C., Allemand, P., Thomas, P., 2010. Morphology and geology of the ILD in Capri/Eos Chasma (Mars) from visible and infrared data. Icarus 207, 175-185.

Flahaut, J., Quantin, C., Clenet, H., Allemand, P., Mustard, J.F., Thomas, P., 2012. Pristine Noachian crust and key geologic transitions in the lower walls of Valles Marineris: insights into early igneous processes on Mars. Icarus 221, 420-435.

Ford, D.C., Williams, P.W. (Eds.), 2007. Karst Hydrogeology and Geomorphology. Wiley, Chichester, London (562 pp.).

Forget, F., Haberle, R.M., Montmessin, F., Levrard, B., Head, J.W., 2006. Formation of glaciers on Mars by atmospheric precipitation at high obliquity. Science 311, 368-371.

Fountain, A.G., Nylen, T.H., MacClune, K.L., Dana, G.L., 2006. Glacier mass balances (1993-2001), Taylor Valley, McMurdo Dry Valleys, Antarctica. J. Glaciol. 52, $451-462$

Fueten, F., Stesky, R., MacKinnon, P., Hauber, E., Zegers, T., Gwinner, K., Scholten, F., Neukum, G., 2008. Stratigraphy and structure of interior layered deposits in west Candor Chasma, Mars, from High Resolution Stereo Camera (HRSC) stereo imagery and derived elevations. J. Geophys. Res. 113, E10008. http://dx.doi.org/10.1029/ 2007JE003053.

Fueten, F., Flahaut, J., Le Deit, L., Stesky, R., Hauber, E., Gwinner, K., 2011. Interior layered deposits within a perched basin, southern Coprates Chasma, Mars: evidence for their formation, alteration, and erosion. J. Geophys. Res. 116, E02003.

Greeley, R., Hyde, J.H., 1972. Lava tubes of cave basalt, Mount-St-Helens, Washington. Geol. Soc. Am. Bull. 83, 2397-2418.

Greeley, R., Spudis, P.D., 1981. Volcanism on Mars. Rev. Geophys. Space Phys. 19, 13-41. Hamblin, W.K., 1976. Patterns of displacement along the Wasatch fault. Geology 4, 619-622.

Hambrey, M.J., Huddart, D., Bennett, M.R., Glasser, N.F., 1997. Genesis of 'hummocky moraines' by thrusting in glacier ice: evidence from Svalbard and Britain. J. Geol. Soc. 154, 623-632.

Harrison, K.R., Chapman, M.G., 2008. Evidence for ponding and catastrophic floods in central Valles Marineris, Mars. Icarus 198, 351-364.

Head, J.W., Marchant, D.R., 2003. Cold-based mountain glaciers on Mars: western Arsia Mons. Geology 31, 641-644.

Head, J.W., Marchant, D.R., 2006. Evidence for global-scale northern mid-latitude glaciation in the Amazonian period of Mars: debris-covered glacier and valley glacier deposits in the $30^{\circ}-50^{\circ} \mathrm{N}$ latitude band. Lunar Planet. Sci. 37 (Abstract 1127). 
Head, J.W., Mustard, J.F., Kreslavsky, M.A., Milliken, R.E., Marchant, D.R., 2003. Recent ice ages on Mars. Nature 426, 797-802.

Head, J.W., Neukum, G., Jaumann, R., Hiesinger, H., Hauber, E., Carr, M., Masson, P., Foing, B., Hoffmann, H., Kreslavsky, M., Werner, S., Milkovich, S., van Gasselt, S., Team, H.C.-I., 2005. Tropical to mid-latitude snow and ice accumulation, flow and glaciation on Mars. Nature 434, 346-351.

Head, J.W., Marchant, D.R., Agnew, M.C., Fassett, C.I., Kreslavsky, M.A., 2006a. Extensive valley glacier deposits in the northern mid-latitudes of Mars: evidence for late Amazonian obliquity-driven climate change. Earth Planet. Sci. Lett. 241, 663-671.

Head, J.W., Nahm, A.L., Marchant, D.R., Neukum, G., 2006b. Modification of the dichotomy boundary on Mars by Amazonian mid-latitude regional glaciation. Geophys. Res. Lett. 33. L08S03. http://dx.doi.org/10.1029/2005GL024360.

Head, J.W., Marchant, D.R., Dickson, J.L., Kress, A.M., Baker, D.M., 2010. Northern mid-latitude glaciation in the late Amazonian period of Mars: criteria for the recognition of debriscovered glacier and valley glacier landsystem deposits. Earth Planet. Sci. Lett. 294, 306-320.

Hoffman, M.J., Fountain, A.G., Liston, G.E., 2008. Surface energy balance and melt thresholds over 11 years at Taylor Glacier, Antarctica. J. Geophys. Res. 113, F04014. http://dx.doi.org/10.1029/2008JF001029.

Holt, J.W., Safaeinili, A., Plaut, J.J., Head, J.W., Phillips, R.J., Seu, R., Kempf, S.D., Choudhary, P., Young, D.A., Putzig, N.E., Biccari, D., Gim, Y., 2008. Radar sounding evidence for buried glaciers in the southern mid-latitudes of Mars. Science 322, 1235-1238.

Howard, A.D., Cutts, J.A., Blasius, K.R., 1982. Stratigraphic relationships within Martian polar cap deposits. Icarus 50, 161-215

Jakosky, B.M., Carr, M.H., 1985. Possible precipitation of ice at low latitudes of Mars during periods of high obliquity. Nature $315,559-561$.

Kadish, S.J., Head, J.W., Barlow, N.G., Marchant, D.R., 2008. Martian pedestal craters: marginal sublimation pits implicate a climate-related formation mechanism. Geophys. Res. Lett. 35, L16104. http://dx.doi.org/10.1029/2008GL034990.

Kargel, J.S., Strom, R.G., 1992. Ancient glaciation on Mars. Geology 20, 3-7.

Kjaer, K.H., Kruger, J., 2001. The final phase of dead-ice moraine development: processes and sediment architecture, Kötlujökull, Iceland. Sedimentology 48, 935-952.

Komatsu, G., Geissler, P.E., Strom, R.G., Singer, R.B., 1993. Stratigraphy and erosional landforms of layered deposits in Valles Marineris, Mars. J. Geophys. Res. 98 (E6), 11105-11121. http://dx.doi.org/10.1029/93JE00537.

Komatsu, G., Ori, G.G., Ciarcelluti, P., Litasov, Y.D., 2004. Interior layered deposits of Valles Marineris, Mars: analogous subice volcanism related to Baikal rifting, southern Siberia. Planet. Space Sci. 52, 167-187.

Kowalewski, D.E., Marchant, D.R., Levy, J.S., Head, J.W., 2006. Quantifying low rates of summertime sublimation for buried glacier ice in Beacon valley, Antarctica. Antarct. Sci. 18, 421-428.

Kowalewski, D.E., Marchant, D.R., Swanger, K.M., Head, J.W., 2011. Modeling vapor diffusion within cold and dry supraglacial tills of Antarctica: implications for the preservation of ancient ice. Geomorphology 126, 159-173.

Kreslavsky, M.A., Head, J.W., 2002. Mars: nature and evolution of young latitude-dependent water-ice-rich mantle. Geophys. Res. Lett. 29, 1719. http://dx.doi.org/10.1029/ 2002GL015392.

Kuhle, M., 1999. Reconstruction of an approximately complete Quaternary Tibetan inland glaciation between the Mt. Everest and Cho Oyu massifs and the Aksai Chin. A new glaciogeomorphological SE-NW diagonal profile through Tibet and its consequences for the glacial isostasy and Ice Age cycle. GeoJournal 47, 3-276.

Laskar, J., Correia, A.C.M., Gastineau, M., Joutel, F., Levrard, B., Robutel, P., 2004. Long term evolution and chaotic diffusion of the insolation quantities of Mars. Icarus 170, 343-364.

Le Deit, L., Le Mouelic, S., Bourgeois, O., Combe, J.P., Mège, D., Sotin, C., Gendrin, A., Hauber, Z., Mangold, N., Bibring, J.P., 2008. Ferric oxides in east Candor Chasma, Valles Marineris (Mars) inferred from analysis of OMEGA/Mars Express data: identification and geological interpretation.J. Geophys. Res. 113, E07001. http://dx.doi.org/10.1029/ 2007JE002950.

Le Deit, L., Bourgeois, O., Mège, D., Hauber, E., Le Mouelic, S., Masse, M., Jaumann, R., Bibring, J.P., 2010. Morphology, stratigraphy, and mineralogical composition of a layered formation covering the plateaus around Valles Marineris, Mars: implications for its geological history. Icarus 208, 684-703.

Le Deit, L., Flahaut, J., Quantin, C., Hauber, E., Mège, D., Bourgeois, O., Gurgurewicz, J., Massé, M., Jaumann, R., 2012. Extensive surface pedogenic alteration of the Martian Noachian crust suggested by plateau phyllosilicates around Valles Marineris. J. Geophys. Res. 117, E00J05. http://dx.doi.org/10.1029/2011JE003983.

Lefort, A., Russell, P.S., Thomas, N., McEwen, A.S., Dundas, C.M., Kirk, R.L., 2009. Observations of periglacial landforms in Utopia Planitia with the High Resolution Imaging Science Experiment (HiRISE). J. Geophys. Res. 114, E04005. http://dx.doi.org/ 10.1029/2008JE003264.

Levrard, B., Forget, F., Montmessin, F., Laskar, J., 2004. Recent ice-rich deposits formed at high latitudes on Mars by sublimation of unstable equatorial ice during low obliquity. Nature 431, 1072-1075.

Levy, J.S., Head, J.W., Marchant, D.R., 2007. Lineated valley fill and lobate debris apron stratigraphy in Nilosyrtis Mensae, Mars: evidence for phases of glacial modification of the dichotomy boundary. J. Geophys. Res. 112, E08004. http://dx.doi.org/10.1029/ 2006JE002852.

Levy, J.S., Head, J.W., Marchant, D.R., 2009. Thermal contraction crack polygons on Mars: classification, distribution, and climate implications from HiRISE observations. J. Geophys. Res. 114, E01007. http://dx.doi.org/10.1029/2008JE003273.

Lucas, A., Mangeney, A., 2007. Mobility and topographic effects for large Valles Marineris landslides on Mars. Geophys. Res. Lett. 34, L10201. http://dx.doi.org/10.1029/ 2007GL029835.

Lucas, A., Mangeney, A., Mège, D., Bouchut, F., 2011. Influence of the scar geometry on landslide dynamics and deposits: application to Martian landslides. J. Geophys. Res. 116, E10001. http://dx.doi.org/10.1029/2011JE003803.
Lucchitta, B.K., 1977. Morphology of chasma walls, Mars. J. Res. U.S. Geol. Surv. 6 651-662.

Lucchitta, B.K., 1978. A large landslide on Mars. Geol. Soc. Am. Bull. 89, 1601-1609.

Lucchitta, B.K., 1979. Landslides in Valles Marineris, Mars. J. Geophys. Res. 84, 8097-8113.

Lucchitta, B.K., 1981. Mars and Earth - comparison of cold-climate features. Icarus 45 , 264-303.

Lucchitta, B.K., 1982. Ice sculpture in the Martian outflow channels. J. Geophys. Res. 87 (B12), 9951-9973.

Lucchitta, B.K., 1999. Geologic map of Ophir and central Candor Chasmata (MTM-05072) of Mars. U.S. Geol. Surv. Misc. Invest. Series Map I-2568.

Lucchitta, B.K., McEwen, A.S., Clow, G.D., Geissler, P.E., Singer, R.B., Schultz, R.A., Squyres, S.W., 1992. The Canyon System on Mars. In: Kieffer, H.H., Jakosky, B.M., Snyder, C.W., Matthews, M.S. (Eds.), Mars. Univ. Arizona Press, Tucson, AZ, pp. 453-492.

Lucchitta, B.K., Isbell, N.K., Howingtonkraus, A., 1994. Topography of Valles-Marineris implications for erosional and structural history. J. Geophys. Res. 99, 3783-3798.

Madeleine, J.B., Forget, F., Head, J.W., Levrard, B., Montmessin, F., Millour, E., 2009 Amazonian northern mid-latitude glaciation on Mars: a proposed climate scenario. Icarus 203, 390-405.

Maizels, J.K., 1992. Boulder ring structures produced during Jökulhlaup flows - origin and hydraulic significance. Geogr. Ann. 74, 21-33.

Malin, M.C., Edgett, K.S., 2001. Mars Global Surveyor Mars Orbiter camera: interplanetary cruise through primary mission. J. Geophys. Res. 106, 23429-23570.

Mangold, N., 2005. High latitude patterned grounds on Mars: classification, distribution and climatic control. Icarus 174, 336-359.

Mangold, N., 2011a. Ice sublimation as a geomorphic process: a planetary perspective. Geomorphology 126, 1-17.

Mangold, N., 2011b. Water ice sublimation-related landforms on Mars. Geol. Soc. Spec. Publ. 356, 133-149.

Marchant, D.R., Head, J.W., 2007. Antarctic Dry valleys: microclimate zonation, variable geomorphic processes, and implications for assessing climate change on Mars. Icarus 192, 187-222.

Marchant, D.R., Lewis, A.R., Phillips, W.M., Moore, E.J., Souchez, R.A., Denton, G.H., Sugden, D.E., Potter, N., Landis, G.P., 2002. Formation of patterned ground and sublimation til over Miocene glacier ice in Beacon Valley, southern Victoria Land, Antarctica. Geol. Soc. Am. Bull. 114, 718-730.

Marshall, S.J., 2005. Recent advances in understanding ice sheet dynamics. Earth Planet Sci. Lett. 240, 191-204.

Massé, M., 2010. Nature et origine des dépôts de sulfate dans les régions équatoriales et polaires de Mars. Comparaison morphologique et minéralogique entre Aram Chaos et la calotte polaire Nord (Nature and origin of sulfate deposits in equatorial and polar regions of Mars. Morphological and mineralogical comparison of Aram Chaos and the North Polar Cap). Ph.D. Thesis, Université de Nantes, France.

Mattson, L.E., Gardner, J.S., Young, G.J., 1993. Ablation on debris covered glaciers: an example from the Rakhiot Glacier, Punjab, Himalaya. IAHS-AISH P, 218, pp. 289-296.

McEwen, A.S., Malin, M.C., Carr, M.H., Hartmann, W.K., 1999. Voluminous volcanism on early Mars revealed in Valles Marineris. Nature 397, 584-586.

Mège, D., Bourgeois, O., 2011. Equatorial glaciations on Mars revealed by gravitational collapse of Valles Marineris wallslopes. Earth Planet. Sci. Lett. 310, 182-191.

Mège, D., Masson, P., 1996a. Stress models for Tharsis Formation, Mars. Planet. Space Sci. 44, 1471-1497.

Mège, D., Masson, P., 1996b. Amounts of crustal stretching in Valles Marineris, Mars. Planet. Space Sci. 44, 749-782.

Metz, J., Grotzinger, J., Okubo, C., Milliken, R., 2010. Thin skinned deformation of sedimentary rocks in Valles Marineris, Mars. J. Geophys. Res. 115, E11004. http://dx.doi.org 10.1029/2010JE003593.

Milkovich, S.M., Head, J.W., 2005. North polar cap of Mars: polar layered deposit characterization and identification of a fundamental climate signal. J. Geophys. Res. 110 E01005. http://dx.doi.org/10.1029/2004JE002349.

Milkovich, S.M., Head, J.W., Marchant, D.R., 2006. Debris-covered piedmont glaciers along the northwest flank of the Olympus Mons scarp: evidence for low-latitude ice accumulation during the late Amazonian of Mars. Icarus 181, 388-407.

Mischna, M.A., Richardson, M.I., Wilson, R.J., McCleese, D.J., 2003. On the orbital forcing of Martian water and $\mathrm{CO}^{2}$ cycles: a general circulation model study with simplified volatile schemes. J. Geophys. Res. 108, E65062.

Molg, T., Hardy, D.R., 2004. Ablation and associated energy balance of a horizontal glacier surface on Kilimanjaro. J. Geophys. Res. 109, D16104. http://dx.doi.org/10.1029/ 2003JD004338.

Molg, T., Hardy, D.R., Kaser, G., 2003. Solar-radiation-maintained glacier recession on Kilimanjaro drawn from combined ice-radiation geometry modeling. J. Geophys. Res. 108, D234731. http://dx.doi.org/10.1029/2003JD003546.

Molg, T., Hardy, D.R., Cullen, N.J., Kaser, G., 2005. Tropical glaciers in the context of climate change and society: focus on Kilimanjaro (east Africa). In: Orlove, B., Beniston (Eds.), Contribution to Mountain Glaciers and Society Workshop. California Univ. Press, Wengen, CA (28 pp.).

Molg, T., Cullen, N.J., Hardy, D.R., Kaser, G., Klok, L., 2008. Mass balance of a slope glacier on Kilimanjaro and its sensitivity to climate. Int. J. Climatol. 28, 881-892.

Mollard, J.D., 2000. Ice-shaped ring-forms in western Canada: their airphoto expressions and manifold polygenetic origins. Quat. Int. 68, 187-198.

Morgenstern, A., Hauber, E., Reiss, D., van Gasselt, S., Grosse, G., Schirrmeister, L., 2007. Deposition and degradation of a volatile-rich layer in Utopia Planitia and implications for climate history on Mars. J. Geophys. Res. 112, E06010. http://dx.doi.org/10.1029/ 2006JE002869.

Nedell, S.S., Squyres, S.W., Andersen, D.W., 1987. Origin and evolution of the layered deposits in the Valles Marineris, Mars. Icarus 70, 409-441.

Okubo, C.H., 2010. Structural geology of Amazonian-aged layered sedimentary deposits in southwest Candor Chasma, Mars. Icarus 207, 210-225. 
Okubo, C.H., Lewis, K.W., McEwen, A.S., Kirk, R.L., 2008. Relative age of interior layered deposits in southwest Candor Chasma based on high-resolution structural mapping. J. Geophys. Res. 113, E12002. http://dx.doi.org/10.1029/2008JE003181.

Ostrem, G., 1959. Ice melting under a thin layer of moraine, and the existence of ice cores in moraine ridges. Geogr. Ann. 41, 228-230.

Page, D.P., 2007. Recent low-latitude freeze-thaw on Mars. Icarus 189, 83-117.

Petit, C., Gunnell, Y., Gonga-Saholiariliva, N., Meyer, B., Séguinot, J., 2009. Faceted spurs at normal fault scarps: insights from numerical modeling. J. Geophys. Res. 114. http:// dx.doi.org/10.1029/2008JB005955 (B05403).

Peulvast, J.P., Masson, P.L., 1993a. Erosion and tectonics in central Valles Marineris (Mars) a new morpho-structural model. Earth Moon Planet. 61, 191-217.

Peulvast, J.P., Masson, P.L., 1993b. Melas Chasma - morphology and tectonic patterns in central Valles Marineris (Mars). Earth Moon Planet. 61, 219-248.

Peulvast, J.P., Mège, D., Chiciak, J., Costard, F., Masson, P.L., 2001. Morphology, evolution and tectonics of Valles Marineris wallslopes (Mars). Geomorphology 37, 329-352.

Quantin, C., Allemand, P., Delacourt, C., 2004a. Morphology and geometry of Valles Marineris landslides. Planet. Space Sci. 52, 1011-1022.

Quantin, C., Allemand, P., Mangold, N., Delacourt, C., 2004b. Ages of Valles Marineris (Mars) landslides and implications for canyon history. Icarus 172, 555-572.

Reynolds, J.M., 2000. On the formation of supraglacial lakes on debris-covered glaciers. In: Nakawo, M., Raymond, C.F., Fountain, A. (Eds.), Debris-Covered Glaciers. Proceedings of the Seattle Workshop, USA, September 2000, 264. IAHS Publication, Wallingford, UK, pp. 153-161.

Rogerson, R.J., Olson, M.E., Branson, D., 1986. Medial moraines and surface melt on glaciers of the Torngat mountains, northern Labrador, Canada. J. Glaciol. 32, 350-354

Rohl, K., 2008. Characteristics and evolution of supraglacial ponds on debris-covered Tasman Glacier, New Zealand. J. Glaciol. 54, 867-880.

Rossi, A.P., Komatsu, G., Kargel, S., 2000. Rock glacier-like landforms in Valles Marineris, Mars. Lunar Planet. Sci. 31 (Abstract 1587).

Schomacker, A., 2008. What controls dead-ice melting under different climate conditions? A discussion. Earth Sci. Rev. 90, 103-113.

Schultz, R.A., 1998. Multiple-process origin of Valles Marineris basins and troughs, Mars. Planet. Space Sci. 46, 827-834.

Schultz, R.A., 2000. Fault-population statistics at the Valles Marineris Extensional Province, Mars: implications for segment linkage, crustal strains, and its geodynamical development. Tectonophysics 316, 169-193.

Séjourné, A., Costard, F., Gargani, J., Soare, R.J., Fedorov, A., Marmo, C., 2011. Scalloped depressions and small-sized polygons in western Utopia Planitia, Mars: a new formation hypothesis. Planet. Space Sci. 59, 412-422.

Shaller, P.J., Komatsu, G., 1994. Landslides on Mars. Landslide News 8, 18-22.

Sharp, R.P., 1973. Mars - troughed terrain. J. Geophys. Res. 78, 4063-4072.
Shean, D.E., 2010. Candidate ice-rich material within equatorial craters on Mars. Geophys. Res. Lett. 37. http://dx.doi.org/10.1029/2010GL045181 (L24202).

Shean, D.E., Head, J.W., Marchant, D.R., 2005. Origin and evolution of a cold-based tropical mountain glacier on Mars: the Pavonis Mons fan-shaped deposit. J. Geophys. Res. 110. http://dx.doi.org/10.1029/2004JE002360 (E05001).

Shugar, D.H., Clague, J.J., 2011. The sedimentology and geomorphology of rock avalanche deposits on glaciers. Sedimentology 58, 1762-1783.

Smith, D.E., Zuber, M.T., Solomon, S.C., Phillips, R.J., Head, J.W., Garvin, J.B., Banerdt, W.B., Muhleman, D.O., Pettengill, G.H., Neumann, G.A., Lemoine, F.G., Abshire, J.B., Aharonson, O., Brown, C.D., Hauck, S.A., Ivanov, A.B., McGovern, P.J., Zwally, H.J., Duxbury, T.C., 1999. The global topography of Mars and implications for surface evolution. Science 284, 1495-1503.

Soare, R.J., Costard, F., Pearce, G.D., Séjourné, A., 2012. A re-interpretation of the recent stratigraphical history of Utopia Planitia, Mars: implications for late-Amazonian periglacial and ice-rich terrain. Planet. Space Sci. 60, 131-139.

Squyres, S.W., 1978. Martian fretted terrain - flow of erosional debris. Icarus 34, $600-613$.

Squyres, S.W., 1979. The distribution of lobate debris aprons and similar flows on Mars. J. Geophys. Res. 84, 8087-8096.

Sugden, D.E., Denton, G.H., Marchant, D.R., 1995. Landscape evolution of the Dry Valleys, Transantarctic Mountains - tectonic implications. J. Geophys. Res. 100, 9949-9967.

Sugden, D.E., Balco, C., Cowdery, S.G., Stone, J.O., Sass, L.C., 2005. Selective glacial erosion and weathering zones in the coastal mountains of Marie Byrd Land, Antarctica. Geomorphology 67, 317-334.

Thaisen, K.T., Schieber, J., Dumke, A., Hauber, E., Neukum, G., 2008. Geomorphologic evidence for significant glacial and fluvial activity in Candor Chamsa, Mars. Lunar Planet. Sci. 39 (Abstract 2358).

Thomas, P.C. Malin, M.C. Edgett, K.S. Carr, M.H., Hartmann, W.K., Ingersoll, A.P., James, P.B., Soderblom, L.A., Veverka, J., Sulliva, R., 2000. North-south geological differences between the residual polar caps on Mars. Nature 404, 161-164.

Vere, D.M., Benn, D.I., 1989. Structure and debris characteristics of medial moraines in Jotunheimen, Norway: implications for moraine classification. J. Glaciol. 120, 276-280.

Warner, N.H., Sowe, M., Gupta, S., Dumke, A., Goddard, K., 2013. Fill and spill of giant lakes in the eastern Valles Marineris region of Mars. Geology. http://dx.doi.org/10.1130/ G34172.1.

Wordsworth, R., Forget, F., Millour, E., Head, J.W., Madeleine, J.-B., Charnay, B., 2013. Global modelling of the early Martian climate under a denser $\mathrm{CO}^{2}$ atmosphere: water cycle and ice evolution. Icarus 222, 1-19.

Wyrick, D., Ferrill, D.A., Morris, A.P., Colton, S.L., Sims, D.W., 2004. Distribution, morphology, and origins of Martian pit crater chains. J. Geophys. Res. 109 (E06005). 